\title{
Portrayals of the Holocaust in English History Textbooks, 1991-2016: Continuities, Challenges and Concerns
}

\section{First Author (corresponding author):}

Prof. Stuart Foster

Executive Director, UCL Centre for Holocaust Education.

20 Bedford Way

London, WC1H 0AL

s.foster@ucl.ac.uk

02076126437

\section{Second Author:}

Dr Eleni Karayianni

Research and Evaluation Officer

UCL Centre for Holocaust Education.

20 Bedford Way,

London, WC1H 0AL

e.karayianni@ucl.ac.uk

02076126437

\section{Funding}

The UCL Centre for Holocaust Education was formed in partnership with the Pears Foundation and with joint funding from the Department for Education.

\section{Notes on Contributors}

Professor Stuart Foster is Executive Director of both the UCL Centre for Holocaust Education and the First World War Centenary Battlefield Tours Programme. His research interests include the teaching, learning and assessment of history, Holocaust education, and the study of school history textbooks and curriculum, nationally and internationally. He has written more than fifty scholarly articles and book chapters focused on teaching and learning history and he has authored or co-authored six books. His most recent co-authored publication was the ground-breaking national study: What do students know and understand about the Holocaust? (2016).

Dr Eleni Karayianni works as a Research and Evaluation Officer at the UCL Centre for Holocaust Education. She is currently involved in the dissemination of the Centre's latest research to educational practitioners and also participates in the design of future research. She holds a PhD in History Education awarded by the UCL Institute of Education in 2012. Her research interests focus on issues of national and international identity formation in history education. She also has wide teaching experience at both primary and university level. 


\title{
Portrayals of the Holocaust in English History Textbooks, 1991-2016: Continuities, Challenges and Concerns.
}

\begin{abstract}
This study examines portrayals of the Holocaust in a sample of 21 secondary school history textbooks published in England between 1991 and 2016. Evaluated against internationally recognised criteria and guidelines, the content of most textbooks proved very problematic. Typically textbooks failed to provide clear chronological and geographical frameworks and adopted simplistic Hitler-centric, perpetrator-oriented narratives. Furthermore, textbooks paid limited attention to pre-war Jewish life, the roots of antisemitism, the complicity of local populations and collaborationist regimes, and the impact of the Holocaust on people across Europe. Based on these critical findings, the article concludes by offering initial recommendations for textbook improvement.
\end{abstract}

\section{Key words}

Holocaust education; textbook research; history teaching; curriculum; history textbooks

\section{Introduction}

This study examines portrayals of the Holocaust in school history textbooks published in England between 1991 and 2016 and written primarily for students at Key Stage 3 (aged between 11 and 14 years). Key Stage 3 (KS3) is the last stage of compulsory history education in England and the Holocaust has been part of the KS3 National Curriculum for history since its inception in $1991 .^{1}$ In fact, it has remained a staple in the school curriculum through five consecutive revisions during the past 25 years. However, despite its prominent place in the curriculum, teaching and learning about the Holocaust often has been hindered by the lack of a clear rationale for its inclusion and absence of teacher guidance on what and how to teach this important subject. ${ }^{2}$

The UCL Centre for Holocaust Education's 2009 national study of teachers' practices revealed that many teachers found the Holocaust a very complex and challenging subject to teach. ${ }^{3}$ Furthermore, $82.5 \%$ of teachers surveyed declared that they had received no formal professional development in teaching the Holocaust and were primarily "self-taught". Given the challenges of teaching this difficult and emotive subject, teachers commonly revealed that they used textbooks to support learning. Indeed, the same study showed that $67 \%$ of teachers were "likely" to use textbooks and further suggested during interviews that textbooks were considered a valuable educational resource. ${ }^{4}$ As the authors of a recent large-scale international study also argued, many teachers assume that because experienced historians and educational experts author textbooks, they provide accurate content and informed pedagogy. As a result, many teachers appear to rely on history textbooks when teaching about the Holocaust. ${ }^{5}$

Since textbooks are widely used in schools, textbook research offers valuable insights into the educational information and content that teachers have at their disposal. ${ }^{6}$ Given Barton and Levstik's emphasis on the way tools constrain and shape thought and action, ${ }^{7}$ the analysis of textbooks as educational tools features as an important dimension of understanding pedagogical practice. Furthermore, although it would be unwise to suggest that student 
knowledge and understanding neatly parallels textbook content, ${ }^{8}$ analysis of school history textbooks potentially offers an important window into how young people learn about the Holocaust. ${ }^{9}$ All these considerations, therefore, provide the rationale for a detailed study of textbook content.

Justification for a targeted focus on textbook content is also buttressed by other important considerations. For example, despite its potential impact on student learning, analysis of textbook content in England is extremely limited. Notably, Marsden has previously referred to the "black hole of textbook research in England" and concluded that in a ten-year period from the late 1980s to the late 1990s, only three articles related to textbook research were published in a sample of twelve leading British educational journals. ${ }^{10}$ In terms of a specific focus on portrayals of Holocaust in England it is astonishing that only two textbook studies have ever been published. ${ }^{11}$ Furthermore, a recent extensive investigation into textbook portrayals of National Socialism and the Holocaust revealed that in a period spanning more than 40 years (1970-2014) a limited number of studies have been undertaken internationally. ${ }^{12}$ Given that a recent UNESCO-GEI study has revealed the Holocaust is taught in more than 111 nation states across the globe and has featured in textbooks potentially read by billions of young people, the paucity of scholarship in this area is remarkable. ${ }^{13}$

Finally, it is important to emphasise that as this study offers a long-term analysis of textbook portrayals of the Holocaust over a 25-year period, it provides an uncommon perspective. In overview, therefore, concerted attention to how the Holocaust is portrayed in English textbooks is, for all the reasons outlined above, both warranted and timely.

\section{Research Aims and Theoretical Framings}

This study was underpinned by three key aims. First, it aimed to more fully appreciate how changes in National Curriculum policy impacted textbook content during the past 25 years. As outlined below, between 1991 and 2016 five distinct versions of the National Curriculum for history have been issued. A key goal, therefore, was to explore the ways in which and the extent to which textbook content was shaped by changing curriculum priorities.

Pursuing this aim the authors were informed by the notion of the "policy cycle" advanced by Bowe and Ball with Gold. ${ }^{14}$ According to these writers, educational policy is constructed and reconstructed within three contexts: a. the "context of influence", where policy is debated and decided by government and other powerful interest groups; b. the "context of text production", where texts deemed to represent policy, such as curricula and textbooks, are constructed and, c. the "context of practice", where policy is interpreted by teachers and students. ${ }^{15}$ Similarly, Westbury also refers to 3 different types of curriculum: "policy" or "prescribed" curriculum, "programmatic" curriculum (such as textbooks and individual school curricula) and "enacted" curriculum (classroom practice). ${ }^{16}$ A central tenet of much of these theoretical framings is the belief that policy expressed in curricula would impact on the content or approach of textbooks.

The theory of the "policy cycle" also encompasses the idea that text production not only influences teaching practice, but is in turn, influenced by it. ${ }^{17}$ In addition, textbooks, as the products of publishing houses that are commercial enterprises, are also influenced and constrained by the desire to maximise profit. ${ }^{18}$ Both practitioners and publishers, therefore, are inevitably influenced in their choices by what the National Curriculum prescribes and in turn, their choices influence textbook content. ${ }^{19}$ 
The second aim of the study was to undertake a detailed analysis of the content of 21 selected textbooks produced over the past 25 years in order to establish whether or not shifts, trends or patterns in textbook narratives were discernible. This approach is informed by the work of Wasburn who argued that a historic view of textbook content is necessary in order to understand contemporary debates surrounding textual inaccuracies and bias. ${ }^{20}$ According to Loewen, the study of how a particular event has been portrayed over time can be labelled as historiography. ${ }^{21}$ Witschonke states that through historiography, "an individual gains a greater understanding of both the content and the times in which it was written". ${ }^{22}$ Using this lens, this study focuses on how representations of the Holocaust have, or have not, changed over time. This longitudinal approach is seen as essential in providing contextual information that can help better understand, assess and critique Holocaust portrayals in textbooks.

The third aim of the study was to critically evaluate the content of the 21 textbooks against recognised international criteria and scholarship focused on teaching and learning about the Holocaust. Indeed, by identifying key problems, commonplace challenges and core issues in textbook content, it was anticipated that important recommendations for improving textbook portrayals of the Holocaust would emerge. For this purpose, the teaching guidelines of the International Holocaust Remembrance Alliance (IHRA) ${ }^{23}$ were used as the primary benchmark against which the 21 textbooks in this study were evaluated. These pedagogical guidelines were developed by experts working in leading institutions in the field of Holocaust education and are internationally recognised and employed by major organisations such as Yad Vashem, the United States Holocaust Memorial Museum, the United Nations and the Organisation for Security and Co-operation in Europe (OSCE). In addition, the findings and recommendations of UNESCO's recent large-scale research into international textbook portrayals of the Holocaust further informed the evaluation of the textbooks analysed for this study. ${ }^{24}$

The use of external criteria does not mean, however, that the authors apply the positivist stance that textbooks can represent reality accurately or that external criteria can judge the objectivity and validity of textbooks in relation to that reality. Informed by Nicholls" "neo-hermeneutics", the authors do not assume a complete objective knowledge of the textbooks being researched, but at the same time, nor are their interpretations conceived as simply subjective or arbitrary. ${ }^{25}$ Adopting this approach, the criteria were used as explicit and public, rather than "objective" benchmarks. Their use in the assessment of content was also seen as a guard against "applying our individual worldviews to texts and enacting our interests in what those texts mean to us". ${ }^{26}$ The use of the IHRA guidelines, therefore, allowed the study to move beyond description of similarities or differences and compelled a more critical and meaningful analysis of textbook content.

\section{History Textbooks in England}

Before moving to discuss the textbook sample and other methodological considerations it is important to recognise that unlike many other countries, state regulated or "approved" textbooks do not exist in England. Rather, individual schools are free to choose which textbooks to purchase from the open market. Furthermore, as no "official" textbooks exist and there is no requirement for schools to update textbooks on a regular basis, it is possible that hundreds of different textbooks may be used for history education at any given time.

Another idiosyncratic feature of textbook provision in England is that as schools often do not equip every pupil with a personal textbook, and because some teachers use textbooks as a source of pedagogical support rather than the central focus of instruction, textbook use typically 
varies from school to school (and from individual classroom to individual classroom). Overall, therefore, it is important to realise that analysis of the content of history textbooks in England can never provide a full picture of what is taught in history classrooms. Despite these limitations, textbooks do play an influential role in history education and undoubtedly have an important impact on students' understanding. For this reason the selection of an appropriate and robust textbook sample proved essential.

\section{Textbook Sample}

To meet the aims of the study it was considered important to analyse a wide range of history textbooks published between the establishment of the history National Curriculum in 1991 and the present day. In total 21 textbooks were selected for analysis because they met the following three criteria:

- They were published for use in the Key Stage 3 history curriculum in England (for students aged 11-14).

- They included focused attention to the Holocaust within a broader framework of significant events of twentieth century history.

- They were produced by a major publishing house, influential in the school textbook market.

To ensure a coherent spread of textbooks produced from 1991 to the present, the sample included 5 textbooks from each of the distinct periods following the publication of new National Curriculum guidelines in 1991, 1995, 1999, as well as the only textbooks published after the 2007 and 2013 guidelines (four and two textbooks respectively). A full list of the textbook sample with publication details appears in the Appendix. In the analysis which follows, textbooks are referred to by a corresponding letter and date of publication (e.g., Textbook A, 1993). All the textbooks included in the sample devoted, on average, 6 pages to the Holocaust. A significant exception was presented by four textbooks - Books L, O, Q, U which devoted 31, 28, 19 and 16 pages respectively. Figure 1 below illustrates the number of pages focused on the Holocaust and the total number of pages in each textbook.

Figure 1: Holocaust coverage in each textbook. 


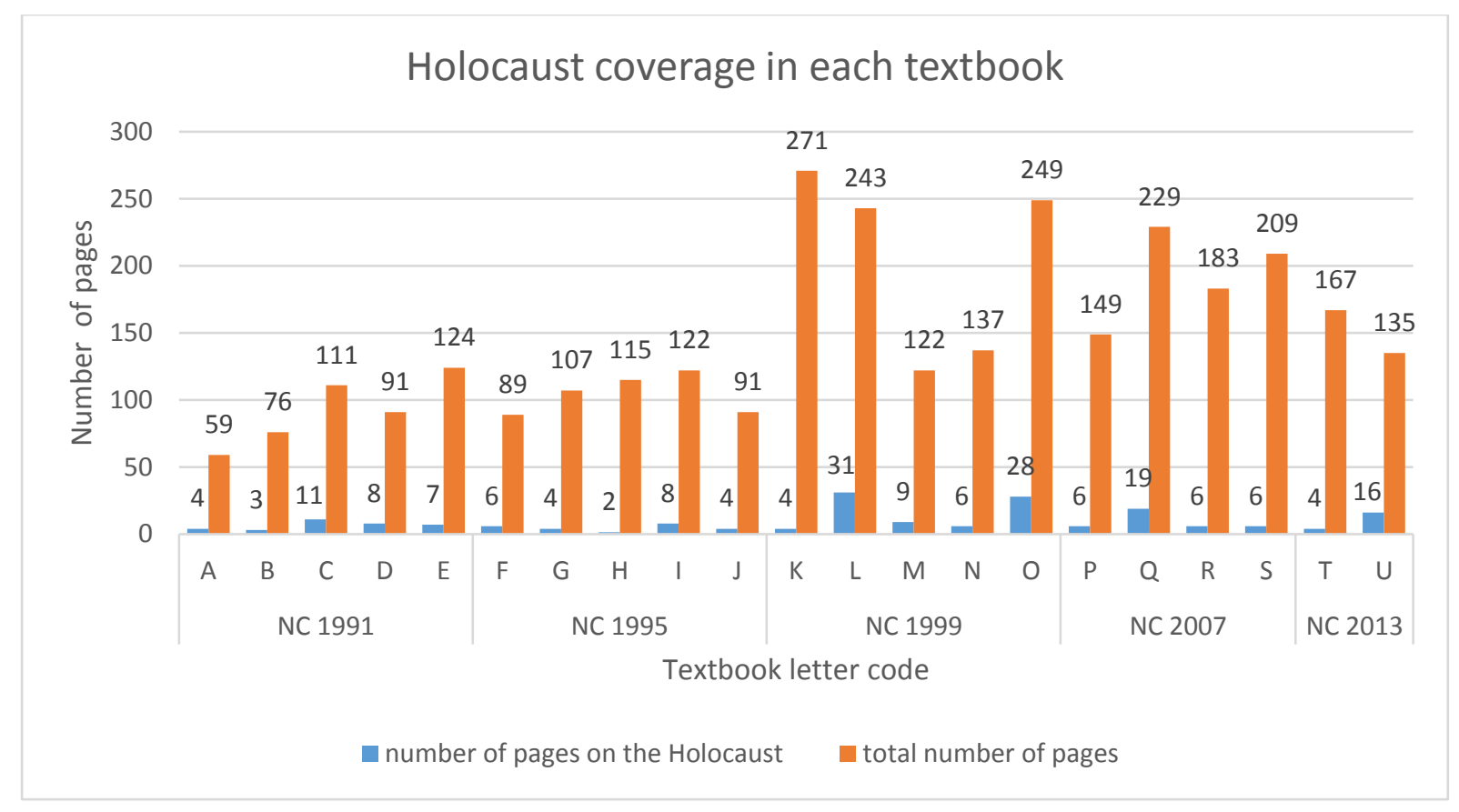

\section{Methodology}

The methodological design of the analysis was informed both by the work of other scholars in the field of textbook research and by the authors' previous research studies. ${ }^{27}$ In addition, research methods were influenced by illustrations of appropriate procedures and techniques found in other textbook studies ${ }^{28}$ and by the work of textbooks analysts who examined Holocaust portrayals over a period of time. ${ }^{29}$

The textbooks in this study were analysed primarily using story line, content and pictorial analysis. Attention was also paid to the pedagogy of the text and the perspective and positionality of the author. For the most part qualitative analysis was employed; however, quantitative measures were also used to explore the relative emphasis on selected areas of content (e.g., the number of images depicting acts of persecution or resistance; the number of written sources containing the perspective of perpetrators or victims). In overarching terms textbook analysis advanced through three phases.

First, multiple-page data collection sheets were developed which served as an organising framework for the analysis of individual textbooks. Informed by the IHRA guidelines, the data collections sheets included spaces to record, for example, the ways and extent to which textbooks portrayed key protagonists; provided chronological and geographical context; addressed issues of complicity and responsibility; and focused on the aftermath of the Holocaust and its contemporary significance and relevance.

Next, the two authors read every section or chapter relevant to coverage of the Holocaust in the 21 textbooks using a constant comparative method. ${ }^{30}$ The authors then discussed and agreed key themes, dominant concepts and primary content areas. Once all the 21 books were analysed and coded using the data collection sheets as an overarching framework, preliminary analysis moved to consider how and in what ways textbooks published in the years following each National Curriculum revision appeared to be influenced by the shifting educational contexts. Accordingly, emerging patterns, commonalities and inconsistencies were recorded and evaluated. Systematic analysis of the textbooks in the third phase used the IHRA educational 
guidelines to assess textbook content and approach. Accordingly, analysis focused on how and to what extent textbook content accorded with the guidelines in a range of key areas.

Overall, analysis of the selected textbooks exposed a complex range of interrelated issues many of which are beyond the scope of this article (e.g., the role of bystanders and rescuers, the use of questions and activities). Nevertheless, contained in the core analytical sections below is specific focus on four major issues and problems identified as consistent throughout the 25 years of the National Curriculum. Before moving to this core discussion, however, attention now turns to an evaluation of how the National Curriculum for history changed over the past 25 years and the extent to which these policy revisions influenced portrayals of the Holocaust in school history textbooks.

\section{The Holocaust in the National Curriculum 1991-2016}

Prior to 1988 individual schools in England were free to decide which subjects to teach and what course content to include in their school curriculum. However, as a result of the Education Reform Act of 1988, a government mandated framework for a National Curriculum was established across a range of key subject areas for students aged from 5 to 16 years of age. Significantly, the establishment of the National Curriculum in 1991 represented a seismic shift in the educational landscape in England and triggered fiercely contested debates about what young people should learn in school, and particularly learn in history. ${ }^{31}$ Despite its controversial introduction, however, five different versions of the National Curriculum have been implemented over the past 25 years and the overarching national framework for history that was first established in 1991 remains in place today. ${ }^{32}$ For the purpose of this study it is particularly notable that mandatory study of the Holocaust has remained a consistent feature of history education in every version of the National Curriculum produced since 1991. Andy Pearce's article in this Special Issue provides an evaluation of the history of the Holocaust in the English curriculum over the last quarter of a century. For the purposes of this chapter, Table 1 below provides a brief, summative overview of how the inclusion of the Holocaust was framed in each National Curriculum document.

Table 1: The Holocaust in the National Curriculum.

\begin{tabular}{|c|l|l|l|}
\hline $\begin{array}{c}\text { National } \\
\text { Curriculum }\end{array}$ & Prescribed Content & Holocaust included in: & Holocaust framed as: \\
\hline 1991 & $\begin{array}{l}\text { Five core units and } \\
\text { three supplementary } \\
\text { units }\end{array}$ & $\begin{array}{l}\text { Core study Unit 5: "The } \\
\text { Era of the Second World } \\
\text { War" }\end{array}$ & $\begin{array}{l}\text { An "experience of war", } \\
\text { alongside "the home front } \\
\text { in Britain" and "the } \\
\text { dropping of the atomic } \\
\text { bombs"33 }\end{array}$ \\
\hline 1995 & Six study units & $\begin{array}{l}\text { Core study unit: "The } \\
\text { Twentieth Century } \\
\text { World" }\end{array}$ & $\begin{array}{l}\text { A "main event" of the } \\
\text { twentieth century34 }\end{array}$ \\
\hline 1999 & $\begin{array}{l}\text { Six main areas of } \\
\text { study }\end{array}$ & $\begin{array}{l}\text { Area of study: "A World } \\
\text { Study after 1900" }\end{array}$ & $\begin{array}{l}\text { One of the four specified } \\
\text { significant events" after } \\
1900 \text { alongside the two } \\
\text { World Wars and the Cold } \\
\text { War35 }\end{array}$ \\
\hline
\end{tabular}




\begin{tabular}{|l|l|l|l|}
\hline 2007 & $\begin{array}{l}\text { Two categories: a. } \\
\text { British History (with } \\
\text { five areas of focus) } \\
\text { and b. European and } \\
\text { world history (with } \\
\text { two areas of focus) }\end{array}$ & $\begin{array}{l}\text { Second area of focus } \\
\text { within European and } \\
\text { World history }\end{array}$ & $\begin{array}{l}\text { Part of the study on } \\
\text { conflict and cooperation } \\
\text { between countries and } \\
\text { people which included } \\
\text { "the nature and impact of } \\
\text { the two world wars and the } \\
\text { Holocaust"36 }\end{array}$ \\
\hline 2013 & Seven study units & $\begin{array}{l}\text { Study unit about } \\
\text { "challenges for Britain, } \\
\text { Europe and the wider } \\
\text { world 1901 to the } \\
\text { present day" }\end{array}$ & $\begin{array}{l}\text { The only topic that pupils } \\
\text { are required to study37 }\end{array}$ \\
\hline
\end{tabular}

In overview, it is evident that over time the Holocaust has gained increasing prominence in the National Curriculum. From 1991 to 2016 it has progressed from being an "experience of war", to a "significant event", to achieving the status of the only compulsory subject of study in the twentieth century. However, the inclusion of the Holocaust in the curriculum typically was not supplemented with guidance for teachers on what and how to teach the topic. Importantly, the first and only governmental guidance was published in 2000 in a non-statutory "Scheme of Work" that provided recommendations on how to structure study units throughout KS3, and what and how to teach a range of historical subjects including the Holocaust. ${ }^{38}$

\section{Curriculum influences on textbooks 1991-2016}

Analysis of the 21 textbooks selected for this study revealed very limited curriculum influence on textbook content. Similarly, other prominent cultural and educational developments that have emerged over the past 25 years appear to have had very limited impact on textbook content. Indeed, it is almost as if the majority of textbook publishers and authors have operated within a vacuum which has generally inured them against external influences. This is perhaps not a surprising finding given the consistent failure of curriculum mandates either to provide a compelling rationale for teaching about the Holocaust, or clear guidance on how to teach or assess this complex subject. The limited influence could also be a result of the preoccupation with generalised 'lessons' against intolerance, prejudice and racism - which Pearce and others describe in this Special Issue - at the expense of specific considerations for content and pedagogy. Furthermore, perhaps the lack of significant change in the content and narrative of these textbooks can be attributed to what Verschaffel and Wils described as the 'power of historical narratives' to remain 'relatively immune to small politically inspired adjustments. ${ }^{39}$

As the following three examples show, it would be incorrect to state that over the past 25 years no curriculum or cultural developments impacted textbook development. However, as these three examples suggest these influences typically were subtle and limited in scope. As shown by Table 2, the first apparent influence of shifting changes to the national curriculum relates to the amount of pages devoted to the Holocaust.

Table 2: Number of pages devoted to the Holocaust 


\begin{tabular}{|cccc|} 
& & pages & book length \\
\hline 1991 & 5 & 6.6 & $7.01 \%$ \\
\hline 1995 & 5 & 4.7 & $4.55 \%$ \\
\hline 1999 & 5 & 15.6 & $7.45 \%$ \\
\hline 2007 & 4 & 9.3 & $4.62 \%$ \\
\hline 2013 & 2 & 10.0 & $7.12 \%$ \\
\hline
\end{tabular}

Of note, the percentage of pages devoted to the Holocaust in the first five textbooks published after the 1991 curriculum was $7 \%$ of the overall content. After the publication of the 1995 'slimmed-down' curriculum, and probably as a result of its requirement for a broader chronological unit on the twentieth century, the percentage dropped to $4.55 \%$ of the overall textbook length. The percentage then rose after the 1999 Curriculum (to $7.45 \%$ of the overall content), perhaps as a result of the topic's reframing as a "significant" event, but a similar reduction was observed after the publication of the 2007 Curriculum (to 4.62\%). It could be argued that this second reduction in textbook coverage was a result of the new curriculum's renewed emphasis on British and world history which had a negative effect on the presence of European history as a whole in these textbooks. ${ }^{40}$

Second, textbooks published after 2000 appeared more likely to include reference to antisemitism than those written before the millennium. For, whereas only two of the 10 textbooks published before 2000 included a reference to antisemitism, it featured in all but one textbook published in subsequent years. The increased inclusion of antisemitism - although, as discussed below, is in many ways flawed - potentially is attributable to the increased emphasis on citizenship issues (such as tackling racism in contemporary British society) in curriculum mandates produced after 1999.

Third, a potentially limited and subtle cultural influence is the appearance of "rescuers" in two textbooks published after 2000. It is not unreasonable to assume that this development was connected to the distribution to all secondary schools of the film Schindler's List which, according to Hector ${ }^{41}$ and Pearce, ${ }^{42}$ became a very popular and widely used resource. However, even if these two textbooks were affected by the prominence of this film, the influence was limited and ephemeral since "rescuers" all but disappeared from the narrative of all subsequent textbooks.

Despite these limited exceptions, for the most part it is extremely difficult to discern any significant relationship between curriculum changes and/or cultural developments that have influenced textbook content in prominent ways. In fact, in some cases, the complete lack of influence is particularly striking. For example, it is revealing that even when some textbooks were revised and reprinted after each new curriculum requirement, their narratives remained almost untouched. For instance, Heinemann's Book A (1991) and its revised Book J (1995) are almost identical despite the implementation of a new curriculum between publication dates. Similarly, the contents of Book E (1993) and Book G (1995) which were written by the same author (Josh Brooman); and Book N (2004), Book P (2009) and Book T (2015) also written be the same main author (Aaron Wilkes), remain strikingly similar across the decades. A further example of the stark lack of influence of curriculum policy on textbook authorship and content is the limited effect of the publication of the ostensibly ground-breaking QCA scheme of work 
focused on the Holocaust. Despite being the first (and last) governmental guidance on how to teach the topic, analysis revealed that it had notable influence on the contents of only one textbook (Book L, 2001). ${ }^{43}$

In a similar vein, other cultural and educational developments also seemed to have had limited impression on the content of history textbooks published since 1991. For example, despite the increased presence of Holocaust survivors in schools in recent decades, ${ }^{44}$ few textbooks included content that captured the perspectives and testimonies of Jewish people. Indeed, apart from the four 'exceptional' textbooks in terms of page coverage (Books L, O, Q, U), in which attention to Jewish agency and action is central, the vast majority of textbooks appear unaffected by the rich and compelling perspectives offered by survivors in educational settings.

Furthermore, Pearce argues that in the late 1990s and beyond, key developments (including the rise in commemoration activities and the establishment of HMD), pushed the Holocaust into the realm of social and moral education where lessons about racism and prejudice could potentially be drawn. ${ }^{45}$ Indeed, Kinloch found that teachers often dealt with the Holocaust as a "moral, social, or spiritual" question rather than a historical one. ${ }^{46}$ Similarly, Russell reported that the majority of teachers taught the Holocaust "from a social and moral perspective and not as history". ${ }^{47}$ The UCL Centre for Holocaust Education's 2009 report into teaching about the Holocaust (discussed further by Pettigrew in this Issue) also underscored these findings. And yet, analysis of the content of textbooks does not seem to reflect these educational developments. Almost no textbook specifically focuses on moral or spiritual issues and the vast majority seldom make any reference to contemporary concerns or "lessons" to be learned from studying the Holocaust.

In overview, analysis of history textbooks reveals that in relation to portrayals of the Holocaust, for the past 25 years the vast majority appear largely unaffected by external influences such as curriculum change or cultural developments. To the contrary, the findings demonstrate a remarkable consistency in the general narrative and tenor of most history textbooks produced over the past three decades. The picture that emerges is, therefore, one of continuity and not change in which, as discussed below, key themes and narratives dominate.

\section{Dominant narratives and problematic portrayals of the Holocaust, 1991-2016}

As indicated above, the teaching guidelines of the International Holocaust Remembrance Alliance (IHRA) were used as the primary benchmark against which the 21 textbooks in this study were evaluated. The guidelines for teachers cover seven primary areas including recommendations on "why, what and how to teach about the Holocaust". ${ }^{48}$ Analysis of portrayals of the 21 history textbooks selected for this study proved a complex undertaking. Overall, however, four overarching patterns or critical themes emerged from detailed study of textbook content. The focus of the next section therefore is to describe and critically evaluate these dominant trends and narratives in more detail.

\section{Lack of Historical Context.}

The IHRA guidelines state that the Holocaust "should be studied in the context of European and global history to give students a perspective on the precedents and circumstances that contributed to it". ${ }^{49}$ The guidelines recommend lessons include information about 
antisemitism, Jewish life before the Holocaust, the Nazi rise to power and the aftermath of world war.

The history of antisemitism was included in a total of 12 textbooks and particularly featured in those published after 2000. The narratives usually included a brief explanation of its meaning - typically defined as 'hatred of the Jews' - and provided some examples of scapegoating or persecution in the past. However, the origins of antisemitism were not sufficiently explored or explained and too often crude generalisations went largely unchallenged. For example, Book L (2001) stated, "Some Christians blamed the Jewish people for the execution of Jesus Christ" (p.147) but did not challenge the accusation. Another example of how textbooks left stereotypical assumptions unchallenged was provided by Book M (2001) which asserted, "Germans were poor and unemployed and wanted someone to blame. They turned on the Jews, many of whom were rich and successful in business" (p.87).

Antisemitic ideas and the persecution of the Jews in Germany during the 1930s was also something that was commonly included in many textbooks, although it is notable that some textbooks talked about racial ideology or hatred for the Jews without using the term 'antisemitism'. A total of 12 textbooks included reference to racial ideas. Arguably, this is a surprisingly low number given the centrality of racial ideology in understanding the factors that contributed to the genocide. Moreover, in those textbooks that did include discussion of racial ideas, rarely were they explained as part of the wider historical context. In fact, too often they were solely attributed to Hitler, as these extracts illustrate:

Hitler had always insisted that all non-Aryan races were inferior. He could now put his insane racial ideas into practice (Book K, 2001, p. 64).

Hitler set out his views on race in his book Mein Kampf; he saw Jews as an inferior race and wanted to destroy them... (Book S, 2010, p. 116).

Furthermore, although it is undoubtedly important to understand that Hitler's ideas gained favour with many Germans in the context of the severe economic and political troubles that confronted the nation in the early 1930s, only four textbooks included any explanation of what these problems were. Of note, even when these explanations did feature, typically they were only a sentence or two in length. For example, Book D (1993) stated that after the First World War "the German economy had collapsed and there was widespread poverty and unemployment" (p. 74). Only one textbook made a serious effort to discuss Germany's problems by including reference to the economic depression, the terms of the Treaty of Versailles, dented national pride, and high levels of unemployment (Book L, 2001).

IHRA recommendations also emphasise it is important to understand Jewish people not simply as victims of the Holocaust, but as people with a long history and rich culture. Certainly, such knowledge also contributes to understanding the significance of the event in terms of the destruction of vibrant Jewish communities across Europe and the resulting loss to contemporary world culture. ${ }^{50}$ It is starkly evident, therefore, that any meaningful appreciation of historical context would need to include from the outset reference to pre-war Jewish life.

Despite the internationally recognised importance of such knowledge, however, the vast majority of textbooks published during the past 25 years failed to include pre-war Jewish life in their textbook portrayals. Of note, only 3 of the 21 textbooks analysed included reference to Jewish life before the war, and these were often very cursory. For example, Book L (2001) 
provided a school photograph of Jewish children in Germany before the war and stated, "there is nothing unusual about the children in the photograph. Jewish children went to school with German children as Jewish families led normal lives in German towns and cities" (p. 148). Book O (2002) mentioned that after the creation of the Weimar Republic, Jews

were given full citizenship and were employed in all areas of work, especially in the professions like law, medicine, as academics in universities and in the civil service... by the 1930s the German Jewry was highly integrated into society and intermarriage between Germans and Jews was high (p. 176).

A final example of how most textbooks paid only limited attention to important historical contexts relates to the end of the Holocaust and, more specifically, to its aftermath. Significantly, only four textbooks featured the Nuremberg trials and this coverage was typically very brief. Arguably more problematic, however, is that only two textbooks included a consideration of the lives of survivors after the war, the practical difficulties they had to face and the emotional trauma they had to endure. Astonishingly, not one of the 21 textbooks analysed described or discussed the consequences of the destruction of entire Jewish communities throughout Europe.

\section{Simplistic Answers to Complex Questions}

IHRA guidelines advise all those involved in Holocaust education to "avoid simple answers to complex questions". ${ }^{51}$ However, analysis revealed that, throughout the 25 -year period of the National Curriculum, textbooks typically provided superficial explanations to key questions such as how and why the Holocaust happened and who was responsible.

For the most part textbooks offered simplistic explanations that centred on Hitler as the main causal factor. Of the 21 books analysed, 17 books explicitly emphasised his pivotal role in the genocide and typically assigned primary responsibility to him. ${ }^{52}$ For example, some textbooks attributed the Holocaust to Hitler's hatred of the Jews:

Hitler has always hated Jews (Book B, 1993; p.68).

...the six death camps were built by the Nazis during the Second World War when they controlled most of Europe. Hitler saw this as an opportunity to get rid of all the people he hated... and especially Jews (Book T, 2015, p.112).

Historians agree that Hitler's vicious antisemitic ideas were the driving force behind the Holocaust (Book U, 2015, p. 48).

Hitler's predominance in the narratives was also apparent when textbooks tried to explain how the Holocaust happened. What was particularly evident was the vast majority of textbooks suggested Hitler as the central protagonist in a policy that saw the treatment of Jews grow in intensity and violence during the 1930s. For example, one textbook stated, "As soon as Hitler became leader of Germany in 1933 he introduced laws and rules that made their lives more difficult" (Book P, 2009, p. 90). In a similar vein, another textbook remarked, "Within days of taking power in 1933, Hitler called for a boycott (ban) on all Jewish businesses" (Book O, 2002, p. 178). Other textbooks pointed to the pivotal role played by Hitler in triggering the violence against Jews committed on November 9, 1938 in the so-called 'Night of Broken Glass' or Kristallnacht. 
The central prominence of Hitler was sustained throughout the chronological narrative of the Holocaust in most textbooks. For example, Hitler was seen as crucial in the ultimate decision to eliminate the Jews of Europe and beyond as the following extracts illustrate:

In 1941 Hitler devised his Final Solution to the Jewish problem (Book A, 1993, p. 44; Book J, 1995, p. 68).

In 1941, Hitler began the policy called the Final Solution. This was an attempt kill all the Jews in Europe (Book K, 2001, p.65).

Although it is undeniable that the vast majority of textbooks adopted a Hitler-centric view of the Holocaust, many also recognised that Hitler's goals were often realised by 'Nazis' within the 'Nazi state'. In other words, most textbooks not only implied that Hitler needed willing Nazis to do his bidding, but also referred to 'Hitler' and 'the Nazis' almost interchangeably. The textbooks were full of references in which the narrative subtly shifted between the two terms as if they are one and the same, as the examples below illustrate:

At first the Nazis used the Jews in the camps as slave labour. But in 1940 or 1941, Hitler decided on the final solution of the Jewish question (Book H, 1995, p. 85).

After the war began in 1939, Jews in countries conquered by the Germans began to suffer at the hands of the Nazis. Hitler established ghettos in German-occupied countries, particularly Poland (Book O, 2002, p. 192).

What appears particularly remarkable is that no textbook offered any robust explanation of the relationship between the German people and the Nazi Party. ${ }^{53}$ Often textbooks gave the impression that the Nazi Party consisted of an elite group loyal to Hitler, rather than a broad based political party for which more than 13 million Germans voted in the early 1930s. Furthermore, no textbook offered any sense of how the Nazi state operated, or any explanation of the ways in which orders were (or were not) translated into action, either in Germany or in occupied territories.

Similarly, no textbook offered any sense of the organisation of the Nazi state and very few provided any true explanation of its key agencies, power structures and the responsibilities of leading individuals. For example, of the 21 textbooks analysed, 12 referenced the SS (Schutzstaffel) but 10 of these provided no explanation of the term whatsoever. ${ }^{54}$ Limited textbook portrayal of key organisational units responsible for the Holocaust was also seen with regard to the Einsatzgruppen. Of the 21 books analysed only six made any direct reference to it $^{55}$ and their role was typically addressed in two or three sentences.

In a similar vein, textbooks often failed to consider the influential role played by leading Nazis. Not including Hitler, the most consistently referenced individual was Himmler, who according to Book C (1994) was tasked with "carrying out the Final Solution", and was mentioned in seven of the 21 books analysed. Other influential Nazis were rarely mentioned and their role in carrying out the genocide was not explained. ${ }^{56}$ For example, extracts from the testimony of the commandant in charge of Auschwitz, Rudolph Hoess, featured in five textbooks, but no explanation of who Hoess was or his place in the Nazi chain of command was offered in the narrative of any book. ${ }^{57}$ Overall, therefore, with the possible exception of Himmler, who appeared in a third of the textbooks, representation of influential Nazis was restricted and 
potentially furthered the impression that it was Hitler supported by largely anonymous Nazis who was responsible for the Holocaust.

With regard to the complex issue of the role of the German people and that of citizens of the countries invaded by the Nazis, half of the textbook sample fundamentally ignored the issue and failed to engage with any discussion of how ordinary people may have in any way become complicit in genocide. However, those textbooks that did acknowledge the German people must had known what was going on, typically suggested that they did not speak out through fear of reprisal. For example, one textbook claimed, "to speak out would have meant imprisonment or death" (Book I, 1999, p. 89) and another asserted most Germans "were too terrified to speak out" (Book K, 2001, p. 65).

Despite the lack of attention to the complicity of ordinary citizens in most textbooks, four (Books M, N, P and T) made reference to the fact that German industry benefitted from Jewish slave labour and suggested that a number of different professions would have been involved in the process of genocide. The following extract, therefore, is indicative of other similar accounts:

Thousands of people, not only loyal Nazis, helped with this [the 'Final Solution'] ordinary people like railway workers, office clerks and policemen. 150 German companies used Auschwitz prisoners as slaves - other firms even competed for the contract to design and build the gas chambers and the ovens in which people were murdered and burned (Book T, 2015, p. 115).

It is important to note, however, that despite the brief exploration of these important issues, the textbooks typically devoted only a few brief paragraphs to them. Indeed, in contrast to the master narrative that clearly focused on the actions of Hitler and the Nazis, attention to the broader complicity of ordinary people appeared extremely limited.

Only one textbook, Book Q (2009) provided more considered attention to issues of complicity. In particular, it devoted one of its 20 pages to the issue of "Who was to blame for the Holocaust?" and moved beyond a focus on Hitler and the Nazis to consider the role of "clerks and civil servants, the police, engine drivers, foremen, train guards, engineers, [and] businesses" (p. 139). Furthermore, in an associated classroom activity, students were asked to consider "levels of blame" and critically reflect on the historian Ian Kershaw's remark that "the road to Auschwitz was built by hatred but paved with apathy." This textbook, however, proved a significant exception to the rule.

Primarily, textbook portrayals of the Holocaust over the past 25 years have focused on the actions of Hitler and his loyal Nazis and only limited and cursory attention has generally been given to broader, deeper and arguably more significant discussions of wider levels of complicity within and across German society. Furthermore, it is striking that no textbook provided coverage of complicity and collaboration in countries occupied by the Germans. It is quite remarkable that, for example, the Vichy government and other Eastern European 'holocausts' remain entirely absent from textbook narratives published over the past three decades.

The complex issue of why the Holocaust happened and who was responsible were, thus, largely left unexplored. Textbooks commonly portrayed Hitler, his ideas, his decisions, and his loyal Nazis, as the reason behind the genocide. Unfortunately, as discussed in the previous section, 
the failure of textbooks to provide important contextual information (e.g., about Germany's severe economic and political problems, the potency of racial ideology, and the development of virulent antisemitism), not only exacerbated the predominance of simplistic answers to complex questions, but also ensured the absence of any meaningful explanation of the Holocaust.

\section{Victims as a Faceless Mass}

IHRA guidelines suggest that "students should be given opportunities to see those persecuted by the Nazis not as a faceless mass of victims but as individuals". They also recommend that students should "consider the history from the perspectives of the victims" and be allowed to "explore a variety of responses of the victims, including the many forms of resistance to the Nazis". ${ }^{58}$ The majority of textbooks analysed, however, appeared guilty of portraying the victims as an anonymous, faceless, and nameless mass. In textbook narratives victims were commonly not named, their perspectives were not included and their experiences were not adequately discussed.

In their portrayals of the early stages of persecution (circa 1933-1938), for example, the majority of textbooks did not attempt to explain how anti-Jewish policies affected the life of Jews, or how Jewish people felt or responded to their severe treatment. Although not typical of most textbooks, Book G (1995) and Book K (2001) did ask students to think about how the lives of ordinary Jewish people were affected by Nazi laws. However, even these two books failed to provide any contextual information to help students answer this question. In fact, only one textbook (Book Q, 2009) included important insights into Jewish responses during the early stages of persecution. This textbook structured attention to early persecution around extracts from the testimony of Holocaust survivor, Frank Bright. The narrative explained how the restrictions affected him and his family and what thoughts and feelings they engendered. Book Q also explained how Jewish lives were adversely affected in the mid-to-late 1930s, why it was difficult for Jewish people to leave Germany at this time and, interestingly, invited students to consider the real consequences for Jewish families. Unfortunately this textbook was not typical of the other 20 books in the sample. For the most part textbooks rarely focused on pre-war Jewish life and the experiences of Jewish people.

In a similar vein, textbook analysis indicated a number of problems with the portrayal of Jewish experiences during the Second World War. In most textbooks, the different ways in which Jewish people were persecuted and murdered received only cursory attention. For example, ghettos were mentioned in 18 of the 21 textbooks, but in most textbooks the detail was extremely limited. Typically, the harrowing experiences of the people confined to ghettos were not addressed, other than some casual and oblique reference to starvation and disease. In fact, only three textbooks provided a detailed discussion of life in the ghettos and included source material from eye-witness testimonies or from Jewish people themselves (Books L, M and Q).

Overall, the experience of the selection and gassing in camps was the one that dominated textbook narratives. All textbooks provided details about the arrival at camps, the selection process and the gassing of victims. Some also provided details on how the bodies were disposed and how hair and teeth were used. However, the important differences between concentration camps and death camps were not usually explained and often the experiences of people in these camps were muddled and confused. This is potentially a problem created by the predominance of Auschwitz as the central example used. It is indicative that each one of the 21 textbooks included in the sample featured Auschwitz in their narratives or in sources and images. ${ }^{59}$ It 
should be noted that the experience of the selection process - so dominant in most textbook narratives - was not typical for the majority of the Holocaust victims. In fact, the experience of Auschwitz was atypical since the majority of the Jewish victims were either deported to killing centres were they were killed within hours of arrival or they were shot in pits near their homes. ${ }^{60}$

As far as victim perspectives are concerned, it is quite telling that, as Figure 3 below indicates, from a total of 21 textbooks, seven textbooks did not include any source - either written or spoken - by a victim or survivor, and an additional eight textbooks included only one such source.

Figure 2: Number of written sources from perpetrators and victims in each textbook.

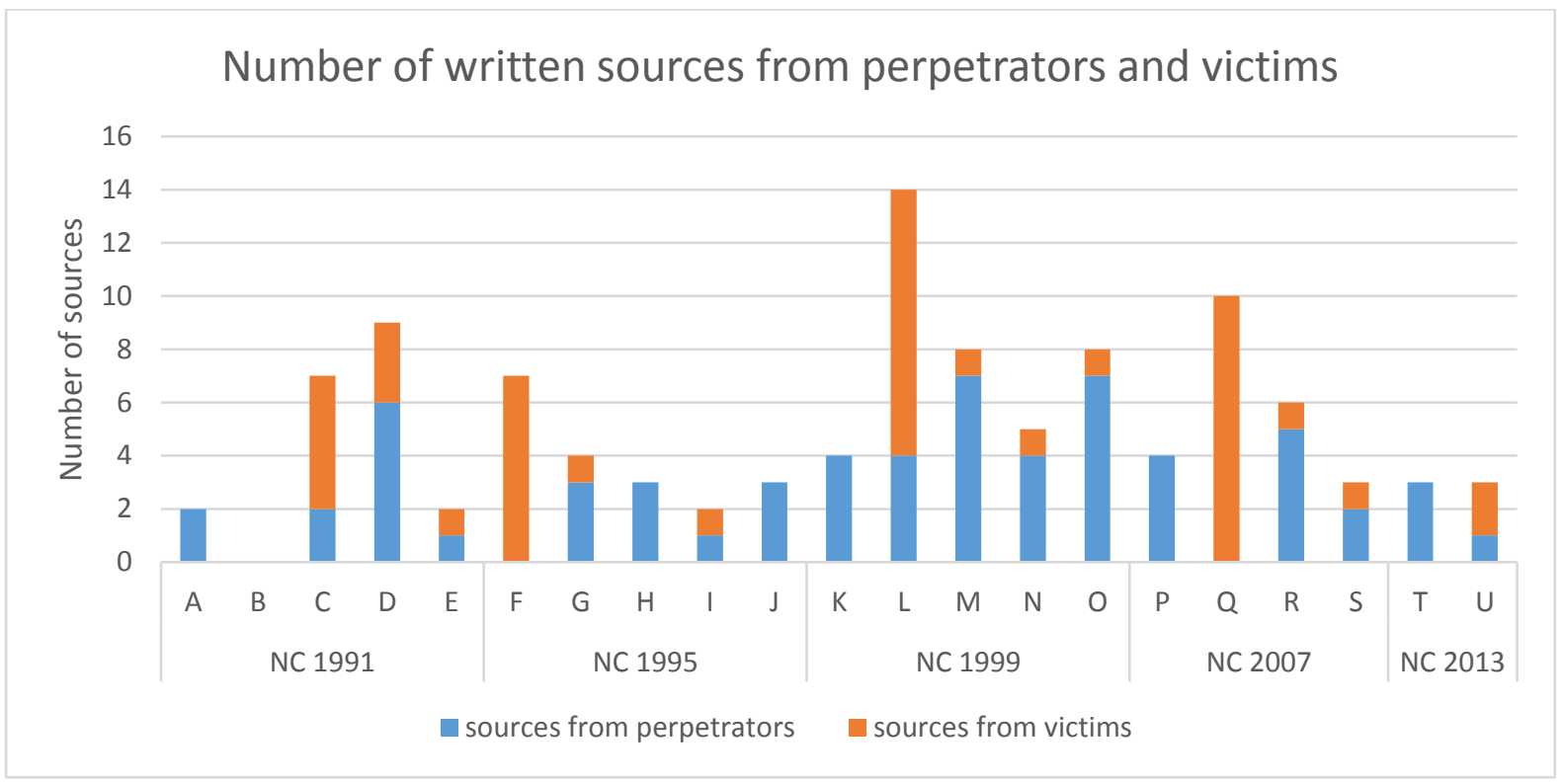

In total, only 4 textbooks included a more substantial account of victim perspectives. For example, Book Q (2009), which followed the story of Frank Bright, structured its text around various aspects of his testimony. Similarly, Book F (1998), included multiple extracts from the testimony of Esther and Perec Zylberberg, while Book L (2001) and Book C (1994) included frequent reference to testimony from the diary of Anne Frank. In general, a very small number of textbooks adopted this approach and few made concerted efforts to 're-humanise' the victims by providing extracts from testimonies, letters or diaries of named individuals. As illustrated above, analysis revealed considerable continuity in textbook representations of perpetrators and victims over the past 25 years. For as Figure 3 shows, despite some notable exceptions, perpetrator-oriented sources (and narratives) have dominated textbooks since 1991.

Analysis of the use of images is also significant in supporting the argument that perpetratororiented perspectives dominate the content of most textbooks at the expense of those of the victims. The majority of textbooks de-humanised victims and denied them their dignity by providing lurid images (usually of mass graves and of people being led to their death or awaiting execution). Of the 21 textbooks analysed, only four textbooks did not include such images. Indeed, some textbooks bombarded students with a variety of images of deprivation and death, in some cases giving the impression that their aim was to shock students rather than to educate them. 
The use of language is also of importance here. Some textbooks adopted the language or perspectives of the perpetrators and described events with alarming apathy. For example, Book $\mathrm{J}$ (1995) described the fate of the Jews as follows:

\begin{abstract}
Various methods were used to kill the Jews. Special death camps were set up to carry out the task. Sometimes the Jews were lined up alongside huge graves and shot so that they fell in but as so many were to be killed, the Germans had to find more efficient ways of extermination. The method they chose was Cyclon B poison gas crystals. As many as 2000 people could be killed at one time. The victims were led into huge chambers, which were then sealed. The gas was released and after about three minutes everyone was dead. Then the bodies were taken away and burned. Useful by-products, like gold teeth, glasses and hair were kept for use by the Nazis (p.44).
\end{abstract}

The use of expressions such as "more efficient ways of extermination" and "useful by-products" uncritically adopted the perspective of the perpetrators and described the events as if they concerned a simple industrialised process, and not the life and death of human beings. Other similarly disturbing examples featured in many of the textbooks analysed.

IHRA guidelines also suggest that efforts to re-humanise Jewish victims should include descriptions of how they responded to the unfolding genocide. In other words, focus should not only attend to what the perpetrators did to Jews, but also consider the actions of Jewish people and the obstacles that constrained their lives. Above all, Jews should not be portrayed simply as passive objects of persecution and murder, but active subjects with agency and value. Yet, only seven textbooks included any discussion, for example, on Jewish resistance. The first such inclusion in any textbook published after 1991 was found in Book F (1998). This textbook stated, "The Jews in the camps did fight back" and, without providing examples, went on to explain that "they were held back by a variety of factors: physical weakness, sickness, lack of weapons, the isolation of camps, disbelief and hope." Book F then asked students to consider how each of these things might have stopped people from fighting back. Taking a somewhat different approach, books I, M, O, Q and U provided examples of such fighting. These books usually referred to the formation of resistance groups, to the Warsaw ghetto uprising, and to escapes and revolts in camps such as in Treblinka and Sobibor. Book O (2002) also included individual acts of courage and books L, M and Q referenced individual and group acts of defiance. For example, Book Q (2009) provides a source written by a Jewish resistance fighter:

Struggling to stay alive another day was a form of resistance. Escaping from the ghetto and hiding in a bunker was resistance. Resistance was giving birth to a child in the ghetto, sharing food with others, praying together, singing in a chorus, studying the Bible, planting flowers, keeping a diary under the shadow of death (p.138).

The topic of resistance received an extraordinarily detailed portrayal in Book U (2015). This textbook devoted a total of eight pages to Jewish responses, which was exactly half the amount allocated to the entire study of the Holocaust in the book. The first pages began with a criticism of school textbooks for commonly providing images of persecution, but rarely showing images of resistance. This, the authors perceptively argued, "can give the misleading and disrespectful impression that Jews went like sheep to the slaughter". The textbook went on to state, "given the obstacles they faced, there was a surprising amount of Jewish resistance to the Nazis. This 
took many forms, not all of them obvious" (p. 54). The pages that followed listed the obstacles to resistance and then all the different kinds of Jewish responses; direct and indirect, active and passive resistance. However, whilst Book $U$ dedicated impressive attention to the subject of resistance, it is important to note that this was extremely unusual.

Overall, therefore, although the issue of Jewish resistance was increasingly included in textbooks published after 2000, it rarely formed a consistent part of the central narrative of the majority of textbooks. Indeed, not all textbooks included a discussion on this issue and some only fleetingly mentioned Jewish resistance. Furthermore, as Figure 4 indicates, textbook portrayal of the Holocaust has been largely focused on images of persecution, rather than ones of resistance. Ultimately, analysis of the narratives and images contained within the 21 textbooks selected for this study, led to the overwhelming conclusion that Jewish people appear more as objects of persecution than as active subjects.

Figure 3: Number of images with Jews as objects of persecution and Jews in resistance in each textbook.

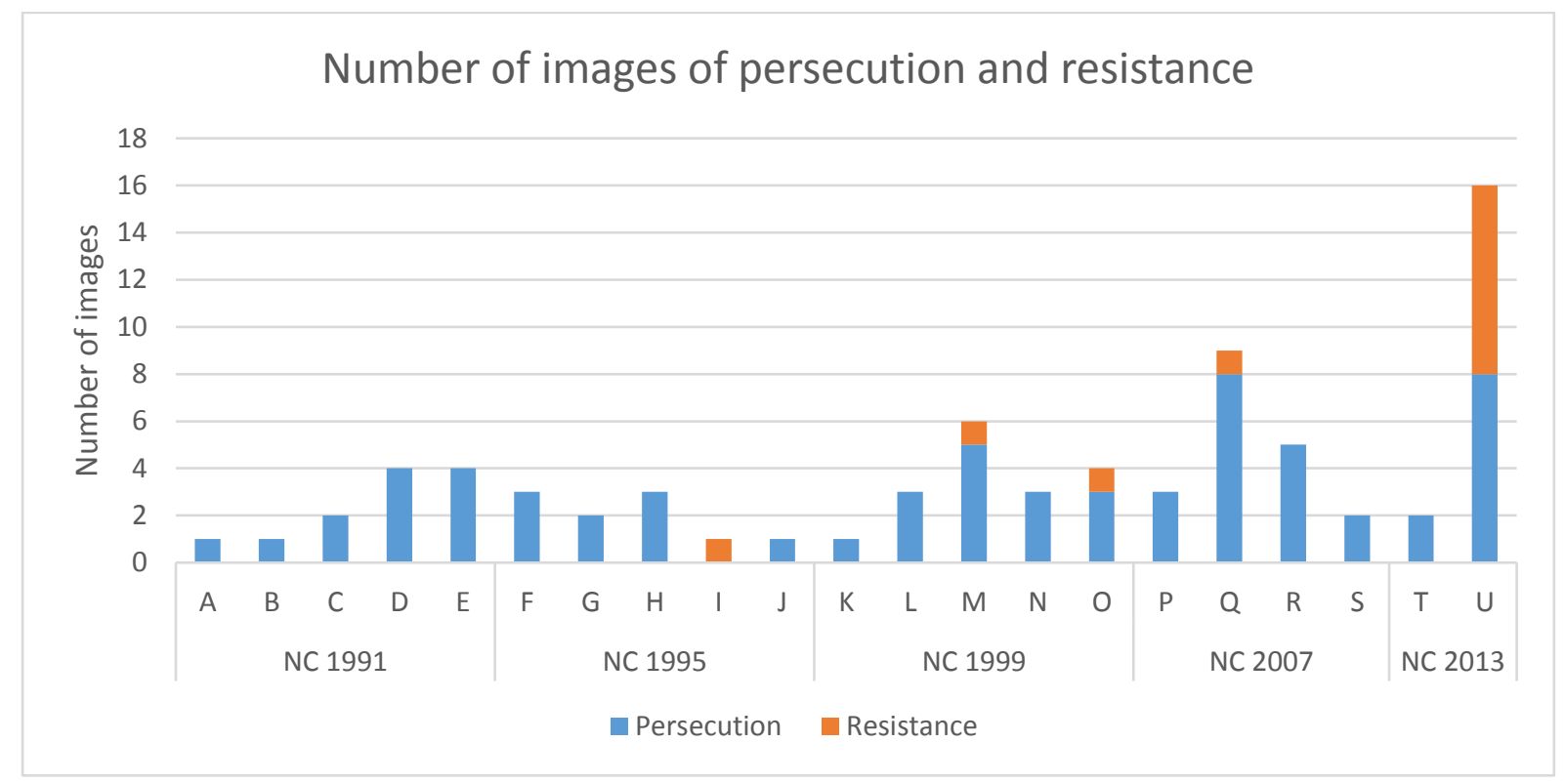

\section{Problematic Chronological and Geographical Frameworks}

IHRA guidelines on how to teach about the Holocaust point to the importance of giving students "a broad and balanced coverage to the subject" and explain that the Holocaust "varied considerably from country to country and at different points in time". ${ }^{61}$ The guidelines on what to teach also include attention to the chronological development of the genocide. Overarching analysis of the 21 textbooks featured in this study, however, identified key problems and issues with the chronological and geographical frameworks employed.

Almost all textbooks included some discussion of the early stages of persecution (1931-1938). In a total of 21 textbooks, only two textbooks did not include any reference to how the persecution started before the Nazi invasion of Poland in September 1939. The textbooks that 
did include such a discussion usually focused on propaganda against Jews, the boycott of Jewish shops, the Nuremberg and other laws and Kristallnacht. In total, social exclusion and legal discrimination was mentioned in 17 textbooks, and violence against Jews before the war was referred to in 15 of the textbooks.

Despite the inclusion of early stages of persecution before the outbreak of war in these textbooks, only one provided an in-depth description of the chronological development of antisemitic policies in relation to the contemporary national and international political context (Book L, 2001). In addition, the ways in which persecution before the war eventually led to a policy of systematic mass murder during the war was not adequately documented. Nor was the gradual radicalisation of Nazi policies sufficiently discussed or explained. It is perhaps notable that only one textbook mentioned the Euthanasia programme and how it contributed to the industrial scale killing of Jews in subsequent years (Book F, 1998).

Furthermore, analysis revealed that the chronology of Jewish persecution and murder during the war years was often dealt with in very rudimentary and ad hoc ways. Arguably, the most informed portrayals of the chronological development of the genocide included the invasion of Poland in 1939, the creation of ghettos, the advance on the Soviet Union in 1941, the actions of the Einsatzgruppen, and the building of death camps as part of the 'Final Solution', primarily after 1942. In this respect textbooks E, G, I, M, O provided a reasonable chronological overview of these key events.

However, the chronological frameworks offered by the majority of textbooks were typically very problematic. For example, some textbooks took a leap from pre-war persecution to 1941 or 1942 and the creation of ghettos or the devising of the Final Solution (Books A, D, J, S). Other textbooks did not provide any sense of chronological development and only mentioned 1942 as the beginning of the 'Final Solution' and the creation of death camps (Book B, C). Similarly, one textbook briefly mentioned the ghettos after the invasion of Poland, before jumping ahead to 1942 and concentrating on the death camps without any sense of pre-war persecution (Book N). In some cases, the creation of ghettos and the actions of the Einsatzgruppen were mentioned with only vague references to when these happened. Indeed such indeterminate references as, "during the war" (Book G, 1995, p.83), "after the conquest of Poland" (Book H, 1995, p.85), "as the war went on" (Book P, 2009, p. 91 and Book T, 2015, p. 112) and "as the army advanced on Russia" (Book F, 1998, p. 64) were commonplace. Astonishingly, one book did not even mention the relationship between the war and Holocaust, thus conveying the impression that everything happened within the borders of Germany (Book K, 2001).

Furthermore, it was particularly notable that two of the four books which were exceptional in terms of the high number of pages allocated to the Holocaust, failed to provide a clear temporal and geographical framework. Indeed, the particular and specific focus of the two textbooks on Jewish experiences (Book Q, 2009) and pictorial evidence (Book U, 2015) had damaging repercussions for the coherence of the overall chronological narrative. In other words, attention to specific issues interrupted the narrative flow and impeded the development of a clear chronological structure.

In general, textbook analysis demonstrated that most textbooks failed to offer a clear representation of what happened from the beginning of war until its end in 1945. For example, three textbooks did not mention mass shootings at all and 13 textbooks provided only cursory reference to the actions of mobile killing squads. On occasions this cursory reference was 
limited to an image of a member of the SS in the act of shooting a Jewish person, with the complete absence of any narrative explanation. This consistent use of short, decontextualised references typically impeded any clear account of when and where mass shootings took place. The fact that only two textbooks (written by the same author) out of the 21 sampled, included a map illustrating the places where mass shooting took place (Books E, 1993 and G, 1995) further substantiates this argument.

Furthermore, as stated in the previous section, textbooks commonly confused concentration camps with death camps. Some textbooks, for example, muddled the two terms and others use them interchangeably, thus giving the impression that two different and valid ways exist to refer to the same thing. For example, Book K (2001) stated:

By 1941, Hitler began the policy called the 'Final Solution'... From Germany, Poland, France, Holland, Czechoslovakia, Russia and all the countries conquered by Hitler, Jews were transported to the concentration camps where they were to be killed (p. 65).

In addition, some textbooks provided maps that illustrated concentration camps in Germany and death camps in Poland without differentiating between the two (Book J, 1995; Book L, 2001). In other cases, concentration camps and death camps were differentiated in maps but their distinctiveness was not explained in the narrative. For example, Book G (1995) did not even mention concentration camps in its narrative despite illustrating such camps in its map. Similarly, Book C (1994) provided a map that illustrated both concentration camps and death camps in Germany and Poland, but the text explained, "the map shows the most notorious of the Nazi death camps" (p. 87). One textbook described the difference between labour camps, concentration camps and death camps, but placed the creation of all of them after 1942. In fact, it is perhaps revealing that only one textbook $(\mathrm{L}, 2001)$ provided a differentiation of camps with a concern for their chronological development. Under the title, "Were all the camps death camps?" the book explained:

After 1941 and the planning of the Final Solution, six camps were established just for the murder of Jews. These were all based in Poland. Over 20 other concentration camps had been running since 1933 as labour camps... (p.157). ${ }^{62}$

It is very evident that clear details of the chronological development of the camp system were commonly absent from most textbooks. Indeed, descriptions often appeared vague and inaccurate and typically textbooks failed to provide a reasonable overview of the function of different camps and where and when they were established.

Finally, analysis revealed problematic textbook portrayals in relation to the geography of the Holocaust. With only 3 exceptions where authors referred to events happening in "much of Europe" (Book A, 1993 and J, 1995) or the Nazis invading "more countries" (Book N) - without specific references to any country - textbooks generally referred to Germany, Poland and the Soviet Union. Other countries were not commonly referred to by name. A total of nine textbooks provided passing reference to other Eastern European countries and seven referred to countries in Western Europe. However, what happened in these countries was not usually explained. 
The only exceptions were a more detailed study presented by Book Q (2009), which followed Frank Bright's story as it unfolded in Czechoslovakia, and Book L (2001), which examined events in Holland during the war through the story of Anne Frank.

The use of maps is especially important in understanding the geography of the genocide. However, only 13 textbooks included maps and not all of these maps provided a clear picture of the geographical scale of the events. For example, some maps were particularly small in size and unclear about what countries they portrayed. Other maps focused specifically on Germany and Poland and even when they named other countries, they included no other information about them to explain their connections to the Holocaust. One map illustrated the location of partisan activity in Eastern Europe and named various places, but it was not clear in which country they were located (Book U). Only 6 textbooks offered a more diverse geographical perspective of the Holocaust, and of these only three portrayed the whole of Europe. Two textbooks provided maps that illustrated the location of "extermination" and concentration camps, the advance of the Einsatzgruppen and the places where mass shootings occurred. These two books also provided an estimated number of victims from each country throughout Europe (Book E and G). Finally, one textbook illustrated the advance of the German army with arrows and dates and, in a second map, the numbers of Jews in each European country along with the location of camps.

In overview, although many textbooks included maps to explain the scope and scale of the Holocaust, these were rarely inclusive of all the nations affected by the Holocaust and specific detail was often inaccurate or confusing. It is also noteworthy that eight textbooks provided no maps to help students appreciate the geography of the Holocaust. Arguably, however, the most troubling finding was that very few textbooks provided any detail about how the Holocaust was operationalised in countries across Europe. Indeed, on the basis of information contained in most textbooks, students would remain unaware that the Holocaust was a continent-wide genocide that targeted Jews wherever they could be found and one that commonly required the collaboration of local European populations.

\section{Problems and Possibilities}

A key finding of this analysis of history textbooks published over the past 25 years is that generally portrayals of the Holocaust did not appear to be unduly influenced by external cultural forces or curriculum change. In fact, it is clear that, with a few exceptions, most textbooks produced between 1991 and 2016 were written by authors who either chose to ignore cultural and policy interventions or remained impervious to their influence. Potentially more alarming, however, is that few textbooks appeared to be influenced by the development of important historical scholarship produced in the past 25 years and more recent research into teaching about the Holocaust.

It is not within the compass of this article to detail the various ways that textbooks failed to draw on advances in scholarship in the past 25 years, however two examples serve to illustrate this problematic issue. First, it is clear that many textbooks presented the Holocaust as a simplistic black and white, good versus evil, issue without considering the complexities of the process of genocide. Recent scholarship, however, has shown that existing and discreet lines between such terms as 'perpetrator', 'collaborator', and 'bystander' were in reality a lot more complex and blurred than most textbook narratives would lead one to believe. ${ }^{63}$ Indeed, especially since the cessation of the Cold War and the opening up of the former Soviet bloc, research into the enactment of the Holocaust across occupied Europe has revealed the genocide 
was an inherently social practice, involving swathes of people. ${ }^{64}$ This ranged from collaborating or allied governments, through paramilitary organizations and auxiliaries, to local populations on the ground. In a similar vein, research conducted in recent decades has illuminated understandings of the role played by many Germans in the Holocaust. ${ }^{65}$ In particular, this research has demonstrated very clearly that most Germans did know about the Holocaust and most either stood by or collaborated. Indeed, few Germans resisted or appeared to object. It is very evident, however, that the narratives of most textbooks were rarely informed by such understandings and as a consequence they failed to engage students with one of the central questions of the Holocaust: how was it that across Europe ordinary people became complicit in the murder of their neighbours?

The second example of how textbooks published in the past 25 years failed to take account of emerging historical scholarship refers to portrayals of Adolf Hitler. As the analysis above has revealed, typically textbooks adopted a Hitler-centric narrative that commonly accentuated the importance of his role in directing and controlling events. In recent decades, however, many historians have stressed the complexity of the decision-making process and the polycratic nature of Nazi rule. ${ }^{66}$ Thus, rather than seeing Hitler as the primary causal agent of the Holocaust, scholars have gradually accepted a more complicated and nuanced reality. Unfortunately, however, the simplistic story of Hitler as an omnipresent and ubiquitous demagogue, skillfully dictating Nazi actions and manipulating the German people is the one to which most textbooks subscribed. In this respect it is noteworthy that one of the few textbooks to devote significant coverage to the Holocaust (Book $U$ ) allocated an impressive six pages, out of a total of 16 pages, to an outdated debate about whether or not the Holocaust was inevitable as soon as Hitler came to power. Essentially, this textbook required students to engage in the tired debate between intentionalist and functionalist perspectives; a polarized dispute which, though influential for a large part of the post-war period, is recognized by most historians today to have been transcended by historiographical developments since the early 1990. In this respect, therefore, it is ironic that rather than engage students in a research informed enquiry around such important issues as Hitler's role; broader complicity among ordinary people; or the actions of Britain and the Allies, the only book to challenge students to consider a different historical interpretation chooses an unfortunate and outdated focus.

What is perhaps most astonishing is that although some exceptions did exist, for the most part textbook portrayals produced in recent years often appeared as flawed and problematic as those published in the early 1990s. In other words, textbooks do not seem to have improved in any consistent way across the 25 -year period. Significantly, almost a quarter of a century ago, in 1992, Supple reviewed a number of existing history textbooks and gloomily concluded that the Holocaust was dealt with in very problematic and superficial ways. She lamented the lack of attention to the history of antisemitism, the prevalence of antisemitic stereotypes, the failure to include Jewish history, agency and resistance, and the absence of any focus beyond Hitler and the Nazis. ${ }^{67}$ Although selected sections of some of the textbooks analysed in this study offered limited improvements to those in Supple's troubling analysis, for the most part - as evidenced above - their narratives provided cause for concern.

Given the limitations of many textbooks it is legitimate to consider their potential impact on teaching and learning about the Holocaust in England in recent years. It is, of course, not suggested here that there is a direct causal relationship between the content of history textbooks and what students know and understand about the Holocaust in school classrooms. Too many variables and issues complicate the educational process to draw firm conclusions about the pedagogical influence of textbooks. Nevertheless it is remarkable how many of the key failings 
in textbook portrayals mirror the recent findings of important national studies conducted into teaching and learning about the Holocaust. For example, consistent with the principal concerns identified in this textbook analysis, the UCL Centre for Holocaust Education's 2009 Report into Teaching About the Holocaust in English Secondary Schools - which drew on the responses of more than 2,000 teachers - concluded that "rather than explore victims' responses to persecution and genocide, teachers were more likely to focus on perpetrator-oriented narratives" ${ }^{68}$ Revealingly only a quarter of teachers surveyed reported that they taught about pre-war Jewish life, whereas the actions of Hitler and the Nazis and explicit focus on Auschwitz typically appeared as curriculum certainties.

More recently, UCL's comprehensive report into students' knowledge and understanding of the Holocaust - which drew on the responses of more than 9,500 students aged 11-18 similarly revealed that limitations in students' knowledge and understanding consistently mirrored problematic textbook portrayals. For example, more than half of students aged 11-14 (56.1\%) believed that Hitler was solely responsible for the Holocaust and very few students of all ages appeared to know about the role played by many Germans or collaborating regimes. Moreover, a striking $68 \%$ of students did not know what antisemitism was, typically lacked knowledge of the distinctiveness of Nazi racial ideology and had little understanding of why Jews were persecuted and murdered. Equally revealing was that few students had a developed geographical and chronological understanding of the Holocaust. Indeed, the majority of students (54.9\%) believed mass murder occurred primarily in Germany, not German-occupied Poland and only $7.4 \%$ of students correctly understood that German invasion of the USSR in June 1941 was the event that primarily triggered the organized mass killing of Jews. ${ }^{69}$ As the authors of the student research argued, these and numerous other equally troubling findings suggest that, "despite the Holocaust being a staple in the curriculum for almost 25 years, students' knowledge and conceptual understanding is often limited and based on inaccuracies and misconceptions". ${ }^{70}$ Although it would be inappropriate to confidently assert that these shortcomings are directly attributable to the content of history textbooks, it is nevertheless plausible that the vast majority of textbooks published in the past 25 years may have inadvertently exacerbated some of the central problems associated with teaching and learning about the Holocaust. Certainly, it is likely that textbooks have not helped to improve students' knowledge, conceptual understanding and historical consciousness of this important subject area.

This study has revealed that although the Holocaust has been mandatory in the secondary school curriculum for 25 years, its representation in textbooks over the same period consistently gives cause for serious concern. It follows, therefore, that to improve textbook portrayals of the Holocaust a series of recommended actions are required. Arguably the recommendations fall into two categories. The first relates to future textbook research and the second focuses on textbook production, content and use. In relation to the first category it is evident that more studies are required which illuminate the various ways that history textbooks are used in specific classroom contexts. Relatedly, more studies examining how students negotiate and learn from history textbooks would prove invaluable in helping to understand their impact and influence. A final recommendation in this category is the need for more research that examines the various factors that influence textbook content. This study has demonstrated that curriculum policies, historical scholarship and classroom-based research appeared to have minimal impact on history textbooks; the question remains therefore what does influence the content of history textbooks? 
With regard to the second category of recommendation (i.e., focused on the production, content and use of textbook) five issues emerge. The first recommendation is that, in the production of textbooks, authors and associated publishing houses need to be more aware of, and responsive to, emerging historical scholarship. As shown above, too many textbooks provide content that is not underpinned by recent historical studies and increasingly accepted interpretations of key issues. Second, authors and publishers should carefully evaluate the content of their history textbooks against such widely accepted international criteria as the IHRA guidelines. In particular, it would be hugely beneficial if textbook authors and publishers considered more thoughtfully the suitability of the aims of their textbooks and what content is most appropriate in meeting these aims. Third, textbook portrayals of the Holocaust would be significantly improved if they were informed by the results of such major international studies as those conducted by the UCL Centre for Holocaust Education. ${ }^{71}$ Currently, too many textbooks exacerbate many of the common myths and misconceptions widely held by secondary school students. As a result, it is vital textbook authors and publishers consider the findings of these national studies and respond in intelligent and meaningful ways.

Fourth, although the authors do not advocate a strict process whereby governments officially "approve" selected textbooks, it is evident the education system needs to pay more attention to the quality of existing textbooks. This potentially might involve the scrutiny of an independent advisory body consisting of educators, historians and critical experts. It is very clear, however, that textbook authors and publishers need to be held more accountable for the quality of their textbooks and the accuracy and appropriateness of the content contained within them. At the very least, checks need to be undertaken to ensure the historical accuracy of core textbook content. The fifth, and arguably the most important recommendation, is that teachers need to be much more knowledgeable and judicious when purchasing and using school textbooks. In making informed judgments about particular textbooks, not only should teachers have access to critical reviews and journal articles such as this, but they should also be given advice and support (e.g., through professional development courses) on how and against what criteria textbooks portrayals of the Holocaust should be judged. Adoption of these key recommendations hopefully would prove significant in critically addressing many of the most urgent issues identified in this textbook analysis. They would also ensure that textbook portrayals of the Holocaust produced over the next twenty-five years are significantly better than those published in the previous twenty-five. 


\section{Notes}

1. Post 14 students have the right to choose whether or not to continue their study of history during the two-year GCSE course (14-16 years). Currently, about 30\% of all 16 years olds, take GCSE history. Beyond 16 years of age students may elect to study 'Advanced Level' (A/AS/A2 level) history. Approximately $6 \%$ of all students study history at Advanced Level. 2. Pearce, Holocaust Consciousness, 83.

3. At the time of the publication of this report the UCL Centre for Holocaust Education was named the Holocaust Education Development Programme (HEDP). The HEDP was established in 2008. It was awarded Centre status by the Institute of Education in 2012 and subsequently renamed as the UCL Centre for Holocaust Education in 2015.

4. Pettigrew et al., Teaching About the Holocaust, 47.

5. Carrier et al., International Status of Education, 21.

6. Pingel, The European Home.

7. Barton and Levstik, Teaching History.

8. Apple and Christian-Smith, Politics of the Textbook.

9. The many ways in which students and teachers understand, negotiate, and transform textual material is a complex process and rarely is textbook content simply accepted, absorbed and then regurgitated by learners. Thus, we cannot assume that what is 'in' the text is actually taught, nor can we assume that what is taught, is actually learned. Teachers and students transform text material when they employ it in classrooms (see, Apple, "Regulating the Text", Foster and Crawford, What Shall We Tell).

10. Marsden, The School Textbook, 57.

11. Foster and Burgess, "Problematic Portrayals"; Wenzeler, "Presentations of the Holocaust".

12. A thorough literature search in libraries and electronic resources found a list of 37 relevant textbook studies internationally that were published in English and focused on National Socialism and/or the Holocaust. See, Foster and Karayianni, "Research into Textbook Portrayals".

13. Carrier et al, ibid.

14. Bowe and Ball, with Gold, Reforming Education, 21.

15. This theory encompasses the notion that powerful interest groups create educational policy and policy texts. Indeed, many textbook theorists and analysts have repeatedly stated that textbooks should be seen as products of the dominant culture and as representations of political, cultural, social and ideological impositions, battles and compromises. See, for example, Apple, "Regulating the Text"; Apple, Official Knowledge; Apple and ChristianSmith, ibid.; De Castell et al., Language, Authority and Criticism; Issitt, "Reflections on the Study of Textbooks"; Nicholls and Foster, "Portrayal of the Soviet Role in WWII"; Williams, Culture and Society 1780-1950. However, it was not the focus of this study to determine whose interests and ideologies were prominent in identified textbooks.

16. Westbury, "Teaching as a Reflective Practice," 15.

17. Bowe et al, ibid.

18. Apple, "The Culture and Commerce of the Textbook"; Crawford and Foster, "The Political Economy"; Foster and Crawford, ibid.; Issitt, ibid.

19. Apple, "The Political Economy of Text Publishing," Wenzeler, ibid.

20. Wasburn, "Accounts of Slavery," 471.

21. Loewen, Teaching What Really Happened.

22. Witschonke, "A 'Curtain of Ignorance'", 147. 
23. The IHRA is an intergovernmental body supported by 28 member states whose purpose is to place political and social leaders' support behind the need for Holocaust education, remembrance, and research both nationally and internationally. See International Holocaust Remembrance Alliance, Teaching Guidelines.

24. Carrier et al., ibid.

25. Nicholls, "Philosophical Underpinnings," 31; Nicholls, "Beyond the National and the Transnational," 92.

26. Krippendorff, Content Analysis, xxi.

27. Crawford and Foster, War, Nation, Memory; Foster, "Struggle for American Identity"; Foster, "The British Empire and Commonwealth"; Foster, "Whose History?"; Foster and Crawford, ibid.; Foster and Burgess, ibid.; Foster and Karayianni, "La Imagen De Los Pueblos Arabe-Islamicos"; Foster and Morris, "Arsenal of Roghteousness?"; Foster and Nicholls, "Interpreting the Past, Serving the Present"; Foster and Nicholls, "America's Role in World War II"; Foster and Rosch, "Teaching World War I from Multiple Perspectives"; Karayianni, "European History and Identity"; Foster et al, "Prospects for Teaching"; Foster, "Constructing the Past"; Bourdillon, History and Social Sciences; Weinbrenner, "Methodologies of Textbook Analysis Used to Date"; Pingel, UNESCO Guidebook on Textbook Research; Crawford, "Researching the Ideological and Political Role"; Mikk, Textbook: Research and Writing; Nicholls, "Methods in School Textbook Research". 28. See, for example, Sleeter and Grant, "Race, Class, Gender"; Hein and Selden, Censoring History; : Crawford, "Constructing National Memory"; Mirkovic and Crawford, "Teaching History"; Nicholls, School History Textbooks.

29. Barbulescu et al., "The Holocaust as Reflected in Communist and Post-Communist Romanian Textbooks"; Firer, "The Holocaust in History Textbooks"; Frankl, "Holocaust Education in the Czech Republic"; Frohnert, "We Want to Learn from the Past"; Michaels, "Holocaust Education in the 'Black Hole of Europe'"; Witschonke, ibid.

30. Glaser, "The Constant Comparative Method", 436.

31. Crawford, History of the Right; Dickinson, School Subject Teaching; Foster, "Politics, Parallels, and Perennial Curriculum Questions"; Haydn, "History"; Phillips, History Teaching, Nationhood and the State; Sylvester, "Change and Continuity".

32. One of the central educational policies of the current Conservative government is to promote the growth of secondary school 'academies'. In 2016 almost two-thirds of secondary schools are academies and it is expected that this number will grow. Significantly academies are not compelled to follow the National Curriculum. It is, therefore, very likely that in future years the National Curriculum will lose its influence.

33. Department of Education and Science, History in the National Curriculum, 45.

34. Department for Education, History in the National Curriculum, 13.

35. Department for Education and Employment, History: The National Curriculum for England, 22.

36. Qualifications and Curriculum Authority, History: Programme of Study for Key Stage 3, 116.

37. Department for Education, History Programme of Study, 210.

38. Qualifications and Curriculum Authority, Schemes of Work.

39. Verschaffel and Wils, "History Education", 2.

40. Karayianni found that textbooks published after the National Curriculum 2007 had increased content on Britain with topics such as the health care system, trade unions, Britain in the 50s and 60s, the Edwardian 'golden summer' commonly featured. She also reported an increased tendency to connect Britain with the world and the inclusion of new world history topics such as the Civil Rights Movement in the USA, the Depression, Mao's China, 
intervention in Afghanistan, terrorism, and emigration. As a result of these efforts, European history received even less attention than in previous textbooks. See Karayianni, ibid., 232.

41. Hector, "Teaching the Holocaust in England".

42. Pearce, ibid.

43. The textbooks that were published after Curriculum 2000 and the publication of the QCA Scheme of Work pay increased attention to the topic of resistance; a topic that was included in the guidance. However, it is difficult to determine whether textbook authors were influenced by the Scheme or whether this was a result of other factors.

44. Pearce, ibid., 65.

45. Ibid.

46. Kinloch, "Review Essay," 44.

47. Russell, Teaching the Holocaust, 8.

48. IHRA, ibid.

49. Ibid.

50. Ibid.

51. Ibid.

52. Of the 4 books whose authors did not ascribe primary responsibility to Hitler, typically they focused in general terms on Nazi actions against the Jews without directly mentioning Hitler in the main narrative (although one does recognize the importance of Hitler's views in an accompanying source). Two of these four books ( $E$ and $G$ ) were written by the same author, Josh Brooman.

53. Book L suggests some reasons why Germans supported Hitler by including reference to Germany's problems during the 1930s.

54. Of the two books which offered any detail, one simply states, "The German SS forces were responsible for the killing of approximately six million Jews in Europe during the Holocaust" (Book L, 2001, p. 156), whilst the other offers a more detailed explanation of how the SS as an "elite group of committed Nazis" were central to the organisation and management of the industrial killing of Jews.

55. An additional two books, authored by Brooman (E and G), referred to "Special Action Groups" rather than the Einsatzgruppen directly.

56. For example, Goebbels is referenced in only 5 books, Goering in 4, Speer and Bormann in two and Eichmann, Heydrich, von Ribbentrop are individually referred to in only one book.

57. It is worth noting that Book A (1993) provides an extract "from the memoirs of Rudolf Hess, Commandant of Auschwitz" (p.44) when the correct spelling of his name should be Höss or Hoess. This mistake confuses Rudolf Höss, Commandant of Auschwitz, with Rudolf Hess, Hitler's deputy in the Nazi Party in the 1930s and early 1940s.

58. IHRA, ibid.

59. Other death camps are mentioned by far fewer textbooks: Chelmo by six textbooks, Majdenek and Treblinka by five, Belzec and Sobibor by four, Dachau by two and Maly Trostinets by one textbook. The reference to concentration camps is even scarcer with only two textbooks referring to Buchenwald and Bergen Belsen.

60. Foster et al, What Students Know, 197.

61. IHRA, ibid.

62. Note that the number of 20 concentration camps represents a significant error in this textbook. The historical record clearly illustrates that from 1933 until 1945 the Nazis created thousands of concentration camps. See, for example, Gilbert, Atlas of the Holocaust. 63. Cesarani and Levine, "Bystanders" to the Holocaust; Hayes and Roth, Oxford Handbook of Holocaust Studies; Klee et al., "The Good Old Days"; Marrus, The Holocaust in History; Matthäus, "Agents of the Final Solution"; Stone, Histories of the Holocaust. 
64. Dean, Collaboration in the Holocaust; Herbert, National Socialist Extermination Policies; Lower, Nazi Empire Building; Snyder, Bloodlands.

65. Aly, Hitler's Beneficiaries; Bajohr, Aryanisation in Hamburg; Bankier, The Germans and the Final Solution; Browning, The Origins of the Final Solution; Friedlander, "The T4 Killers"; Goldhagen, Hitler's Willing Executioners; Hilberg, Perpetrators, Victims, Bystanders; Kershaw, Hitler, the Germans and the Final Solution.

66. Broszat, The Hitler State; Kershaw, The Nazi Dictatorship, Stone, ibid.

67. Supple, Teaching of Nazi Holocaust.

68. Pettigrew et al., ibid, 8.

69. Foster et al, ibid., 190.

70. Ibid, 1.

71. Pettigrew et al., ibid; Foster et al, ibid. 
Appendix: The textbook sample.

\begin{tabular}{|c|c|c|c|c|c|}
\hline Textbook & Curriculum & Title & Authors & Date & Publisher \\
\hline $\mathbf{A}$ & 1991 & $\begin{array}{l}\text { Heinemann } \\
\text { History: The era of } \\
\text { the second world } \\
\text { war }\end{array}$ & $\begin{array}{l}\text { Kelly, N. and } \\
\text { Whittock, M. }\end{array}$ & 1993 & Heinemann \\
\hline B & 1991 & $\begin{array}{l}\text { The era of the } \\
\text { second world war }\end{array}$ & DeMarco, N. & 1993 & Oxford UP \\
\hline $\mathrm{C}$ & 1991 & $\begin{array}{l}\text { The era of the } \\
\text { second world war }\end{array}$ & $\begin{array}{l}\text { Cootes, R.J. } \\
\text { and } \\
\text { Snellgrove, } \\
\text { L.E. }\end{array}$ & 1994 & Nelson \\
\hline D & 1991 & $\begin{array}{l}\text { The era of the } \\
\text { second world war }\end{array}$ & $\begin{array}{l}\text { Lancaster, } \mathrm{T} \text {. } \\
\text { and Lancaster } \\
\mathrm{S} \text {. }\end{array}$ & 1993 & $\begin{array}{l}\text { Causeway } \\
\text { Press }\end{array}$ \\
\hline $\mathbf{E}$ & 1991 & $\begin{array}{l}\text { The era of the } \\
\text { second world war }\end{array}$ & Brooman, J. & 1993 & Longman \\
\hline $\mathbf{F}$ & 1995 & $\begin{array}{lr}\text { Living } & \text { through } \\
\text { History: } & \text { The } \\
\text { Twentieth } & \text { Century } \\
\text { World } & \\
\end{array}$ & Kelly, N. et al & 1998 & Heinemann \\
\hline $\mathbf{G}$ & 1995 & $\begin{array}{l}\text { The Twentieth } \\
\text { Century World }\end{array}$ & Brooman, J. & 1995 & Longman \\
\hline $\mathbf{H}$ & 1995 & $\begin{array}{l}\text { Access to History: } \\
\text { The Twentieth } \\
\text { Century World }\end{array}$ & Robson, W. & 1995 & Oxford \\
\hline I & 1995 & $\begin{array}{lr}\text { Think } & \text { Through } \\
\text { History: } & \text { Modern } \\
\text { Minds. } & \text { The } \\
\text { Twentieth } & \text { Century } \\
\text { World } & \\
\end{array}$ & $\begin{array}{l}\text { Byrom, J. et } \\
\text { al. }\end{array}$ & 1999 & Longman \\
\hline $\mathbf{J}$ & 1995 & $\begin{array}{l}\text { Heinemann } \\
\text { History: The } \\
\text { Twentieth Century } \\
\text { World }\end{array}$ & $\begin{array}{l}\text { Kelly, N. \& } \\
\text { Whittock, M. }\end{array}$ & 1995 & Heinemann \\
\hline $\mathbf{K}$ & 1999 & $\begin{array}{l}\text { Making History: } \\
\text { World History from } \\
1914 \text { to the Present }\end{array}$ & Culpin, $\mathrm{C}$. & 2001 & Collins \\
\hline $\mathbf{L}$ & 1999 & $\begin{array}{l}\text { Heinemann History } \\
\text { Scheme: Into the } \\
\text { Twentieth Century }\end{array}$ & Kidd, J. et al & 2001 & Heinemann \\
\hline $\mathbf{M}$ & 1999 & $\begin{array}{l}\text { Re-discovering the } \\
\text { Twentieth Century } \\
\text { World. A world } \\
\text { study after } 1900\end{array}$ & $\begin{array}{l}\text { Shephard, C. } \\
\text { \& Shephard, } \\
\text { K. }\end{array}$ & 2001 & Hodder \\
\hline $\mathbf{N}$ & 1999 & $\begin{array}{l}\text { Technology, War } \\
\text { and Identities. A }\end{array}$ & Wilkes, A. & 2004 & Folens \\
\hline
\end{tabular}




\begin{tabular}{|c|c|c|c|c|c|}
\hline & & $\begin{array}{lll}\text { world study after } \\
1900\end{array}$ & & & \\
\hline O & 1999 & $\begin{array}{l}\text { Colonisation and } \\
\text { Conflict 1750-1990 }\end{array}$ & $\begin{array}{l}\text { Collier, M. } \\
\text { and Marriott, } \\
\text { B. }\end{array}$ & 2002 & Heinemann \\
\hline $\mathbf{P}$ & 2007 & $\begin{array}{l}\text { Technology, War } \\
\text { and Identities. A } \\
\text { world study after } \\
1900\end{array}$ & $\begin{array}{l}\text { Wilkes, A. \& } \\
\text { Ball. J. }\end{array}$ & 2009 & Oxford \\
\hline $\mathbf{Q}$ & 2007 & SHP History Year 9 & $\begin{array}{l}\text { Banham, D. } \\
\text { ans Luff, I. }\end{array}$ & 2009 & $\begin{array}{l}\text { Hodder } \\
\text { Education }\end{array}$ \\
\hline $\mathbf{R}$ & 2007 & $\begin{array}{l}\text { History in Progress: } \\
1901 \text { to Present Day }\end{array}$ & $\begin{array}{l}\text { Clayton, S. et } \\
\text { al }\end{array}$ & 2009 & Heinemann \\
\hline $\mathbf{S}$ & 2007 & $\begin{array}{l}\text { Collins Key Stage } 3 \\
\text { History: Book 3: } \\
\text { Twentieth Century }\end{array}$ & $\begin{array}{l}\text { Wilkinson, A. } \\
\text { et al }\end{array}$ & 2010 & $\begin{array}{l}\text { Collins } \\
\text { Education }\end{array}$ \\
\hline $\mathbf{T}$ & 2013 & $\begin{array}{l}\text { Technology, War } \\
\text { and Independence } \\
\text { 1901-Present day }\end{array}$ & Wilkes, A. & 2015 & $\begin{array}{l}\text { Oxford } \\
\text { University } \\
\text { Press }\end{array}$ \\
\hline $\mathbf{U}$ & 2013 & $\begin{array}{l}\text { Making Sense of } \\
\text { History: } 1901- \\
\text { present day }\end{array}$ & Bates, N. et al & 2015 & $\begin{array}{l}\text { Hodder } \\
\text { Education }\end{array}$ \\
\hline
\end{tabular}




\section{Bibliography}

Aly, Goetz. Hitler's Beneficiaries: Plunder, Racial War and the Nazi Welfare State. New York: Henry Holt \& Co., 2007.

Apple, Michael W., and Linda K. Christian-Smith, eds. The Politics of the Textbook. London Routledge, 1991.

Apple, Michael. "Regulating the Text: The Socio-Historical Roots of State Control." In Textbooks in American Society. Politics, Policy, and Pedagogy, edited by Philip G. Altbach, Gail P. Kelly, Hugh G. Petrie and Lois Weis. Albany: State University of New York Press, 1991.

Apple, Michael. "The Culture and Commerce of the Textbook." In The Politics of the Textbook, edited by Michael W. Apple and Linda K. Christian-Smith. London Routledge, 1991.

Apple, Michael. "The Political Economy of Text Publishing." In Language, Authority and Criticism, edited by Suzanne De Castell, Allan Luke and Carmen Luke. London Falmer Press, 1989.

Apple, Michael. Official Knowledge: Democratic Education in a Conservative Age (2nd Edition). London: Routledge, 2000.

Bajohr, Frank. Aryanisation in Hamburg: The Economic Exclusion of the Jews and the Confiscation of Their Property in Nazi Germany. New York and Oxford: Berghahn Books, 2002.

Bankier, David. The Germans and the Final Solution: Public Opinion under Nazism. Oxford: Blackwell, 1992.

Barbulescu, Ana, Laura Degeratu, and Cosmina Gusu. "The Holocaust as Reflected in Communist and Post-Communist Romanian Textbooks." Interculutral Education 1-2, no. 41-60 (2013).

Barton, Keith C., and Linda S. Levstik. Teaching History for the Common Good. London: Lawrence Erlbaum, 2004.

Bourdillon, Hilary. History and Social Sciences - Methodologies of Textbook Analysis. Report of the Educational Research Workshop Held in Braunschweig (Germany) 11-14 September 1990. Amsterdam: Swets \& Zeitlinger, 1992.

Bowe, Richard, Stephen Ball, and Anne Gold. Reforming Education and Changing Schools: Case Studies in Policy Sociology. London: Routledge, 1992.

Broszat, Martin. The Hitler State: The Foundation and Developments of the Internal Structure of the Third Reich. London: Longman, 1981.

Browning, Christopher. The Origins of the Final Solution: The Evolution of Nazi Jewish Policy, September 1939-March 1942. Lincoln, NE and Jerusalem: University of Nebraska Press and Yad Vashem, 1992. 
Carrier, Peter, Eckhardt Fuchs, and Torben Messinger. The International Status of Education About the Holocaust. A Global Mapping of Textbooks and Curricula. Paris: UNESCO, 2015.

Cesarani, David, and Paul Levine. "Bystanders" to the Holocaust: A Re-Evaluation. London: Frank Cass, 2002.

Crawford, Keith, and Stuart Foster. "The Political Economy of History Textbook Publishing in England." In School History Textbooks across Cultures: International Debates and Perspectives, edited by Jason Nicholls, 93-104. Oxford: Symposium Books, 2006.

Crawford, Keith, and Stuart Foster. War, Nation, Memory: International Perspectives on World War II in School History Textbooks. Charlotte, N.C: Information Age Publishing, 2007.

Crawford, Keith. "A History of the Right: The Battle for Control of National Curriculum History 1989-1994." British Journal of Educational Studies 43, no. 4 (1995): 433-56.

Crawford, Keith. "Constructing National Memory: The 1940/41 Blitz in British History Textbooks." Internationale Schulbuchforschung 23, no. 2 (2001).

Crawford, Keith. "Researching the Ideological and Political Role of the History Textbook Issues and Methods." International Journal of Historical Learning, Teaching and Research 1, no. 1 (2000): 81.

De Castell, Suzanne, Allan Luke, and Carmen Luke, eds. Language, Authority and Criticism. Readings on the School Textbook. London: The Falmer Press, 1989.

Dean, Martin. Collaboration in the Holocaust: Crimes of the Local Police in Belorussia and Ukraine, 1941-1944. London: Palgrave Macmillan, 2000.

Department for Education and Employment. History: The National Curriculum for England. London HMSO, 1999.

Department for Education and Science. History in the National Curriculum. London: HMSO, 1991.

Department for Education. History in the National Curriculum. London: HMSO, 1995.

Department for Education. History Programmes of Study: Key Stage 3. National Curriculum in England. London: Crown, 2013.

Dickinson, Alaric. School Subject Teaching: The History and Future of the Curriculum. Edited by A. Kent London: KoganPage, 2000.

Firer, Ruth. "The Holocaust in History Textbooks." In The Treatment of the Holocaust in Textbooks: The Federal Republic of Germany, Israel, the United States of America, edited by Randolph L. Braham. New York: Columbia University Press, 1987.

Foster, Stuart J., W. J. Morris, and L. O. Davis. "Prospects for Teaching Historical Analysis and Interpretation: National Curriculum Standards for History Meet High School History Textbooks." Journal of Curriculum and Supervision 11 (1996): 367-85. 
Foster, Stuart, Alice Pettigrew, Andy Pearce, Rebecca Hale, Adrian Burgess, Paul Salmons, and Ruth-Anne Lenga. What Do Students Know and Understand About the Holocaust? Evidence from English Secondary Schools. London: UCL Institute of Education, 2016.

Foster, Stuart, and Adrian Burgess. "Problematic Portrayals and Contentious Content. Representations of the Holocaust in English History Textbooks." Journal of Educational Media, Memory, and Society 5, no. 2 (2013): 20-38.

Foster, Stuart, and Eleni Karayianni. "La Imagen De Los Pueblos Arabe-Islamicos En Los Libros De Texto Ingleses De Historia." In Conociendo Al Otro. El Islam Y Europa En Sus Manuales De Historia, edited by ATMAN Foundation. Madrid: Ministerio de Educacion, Politicaocial y Deporte, 2008.

Foster, Stuart, and Jason Nicholls. "America's Role in World War Ii: An Analysis of History Textbooks from England, Japan, Sweden, and the United States." Journal of Curriculum and Supervision 20, no. 3 (2005): 214-33.

Foster, Stuart, and Keith Crawford, eds. What Shall We Tell the Children? International Perspectives on School History Textbooks. Greenwich, Connecticut: Information Age Publishing, 2006.

Foster, Stuart, and Richard Rosch. "Teaching World War I from Multiple Perspectives." Social Education 61, no. 7 (1997): 429-34.

Foster, Stuart, and W. J. Morris. "Arsenal of Roghteousness? Treatment of the Atomic Bombing in English and U.S. History Textbooks." Curriculum 15, no. 3 (1994): 16373.

Foster, Stuart. "'Interpreting the Past, Serving the Present": Us and English Textbook Portrayals of the Soviet Union During World War II." In Understanding History: International Review of History Education, edited by Jason Nicholls, Stuart Foster, Rosalyn Ashby, Peter Gordon and Peter Lee, 173-87. London: Routledge, 2005.

Foster, Stuart. "Constructing the Past to Serve the Present: Nation, Identity and World War II in French School History Textbooks." International Journal of Social Education 24, no. 2 (2010): 193-220.

Foster, Stuart. "Politics, Parallels, and Perennial Curriculum Questions: The Battle over School History in England and the United States." The Curriculum Journal 9, no. 2 (1998): 153-64.

Foster, Stuart. "Research into Textbook Portrayals of National Socialism and the Holocaust: Issues, Challenges and Future Directions." In Palgrave Handbook of Textbook Studies, edited by Eckhardt Fuchs and Barbara Christophe. London: Palgrave, 2016.

Foster, Stuart. "The British Empire and Commonwealth in World War Ii: Selection and Omission in English History Textbooks." International Journal of Historical Learning, Teaching and Research 5 (2005): 1-19.

Foster, Stuart. "The Struggle for American Identity: Treatment of Ethnic Groups in United States History Textbooks ". History of Education 28, no. 3 (1999): 251-79. 
Foster, Stuart. "Whose History? Portrayal of Immigrant Groups in Us History Textbooks, 1800-Present." In What Shall We Tell the Children? International Perspectives on School History Textbooks, edited by Stuart J. Foster and Keith A. Crawford, 155-78. Greenwich, USA: Information Age Publishing, 2006.

Frankl, Michal. "Holocaust Education in the Czech Republic, 1989-2002." Interculutral Education 14, no. 2 (2010): 177-89.

Friedlander, Henry. "The T4 Killers: Berlin, Lublin, San Sabba." In The Holocaust and History: The Known, the Unknown, the Disputed and the Re-examined, edited by Michael Berenbaum. Bloomington, IN: Indiana University Press, 1998.

Frohnert, Par. ""We Want to Learn from the Past". The Holocaust in German History Schoolbooks before and after Reunification." In The Holocaust on Post-War Battlefields. Genocide as Historical Culture, edited by Klas-Goeren Karlsson and Ulf Zander. Malmo: Sekel Bokfoerlag, 2006.

Gilbert, Martin. Atlas of the Holocaust. London: William Morrow \& Company, 1993.

Glaser, Barney G. "The Constant Comparative Methods of Qualitative Analysis." Social Problems 12, no. 4 (1965): 436-45.

Goldhagen, Daniel. Hitler's Willing Executioners: Ordinary Germans and the Holocaust. New York: Vintage Books, 1996.

Haydn, Terry. "History." In Rethinking the School Curriculum: Values, Aims and Purposes, edited by John White. London: RoutledgeFalmer, 2004.

Hayes, Peter, and John k. Roth, eds. The Oxford Handbook of Holocaust Studies. Oxford: Oxford University Press, 2012.

Hector, Susan. "Teaching the Holocaust in England." In Teaching the Holocaust: Educational Dimensions, Principles and Practice, edited by Ian Davies. London: Continuum, 2000.

Hein, Laura, and Mark Selden, eds. Censoring History. Citizenship and Memory in Japan, Germany, and the United States. London: M.E. Sharpe, 2000.

Herbert, Ulrich, ed. National Socialist Extermination Policies: Vol:2, War and Genocide. New York and Oxford: Berghahn Books, 2000.

Hilberg, Paul. Perpetrators, Victims, Bystanders: The Jewish Catastrophe. New York: Harper Perennial, 1993.

International Holocaust Remembrance Alliance. "Teaching Guidelines." https://www.holocaustremembrance.com/educate/teaching-guidelines, accessed 24/03/2016.

Issitt, John. "Reflections on the Study of Textbooks." History of Education 33, no. 6 (2004): 683-96. 
Karayianni, Eleni. European History and Identity in England's History Education. A Study of Curriculum, Policy, Textbooks and Teachers' Practice, Phd Thesis. London: Institute of Education, 2012.

Kershaw, Ian. Hitler, the Germans and the Final Solution. New Haven, CT: Yale University Press, 2008.

Kershaw, Ian. The Nazi Dictatorship: Problems and Perspectives of Interpretation. London: Hodder, 2000.

Kinloch, Nicholas. "Review Essay: Learning About the Holocaust: Moral or Historical Question?" Teaching History 93 (1998): 44-46.

Klee, Ernst, Willi Dresden, and Volker Reiss, eds. "The Good Old Days": The Holocaust as Seen by Its Perpetrators and Bystanders. New York: Konechy \& Konecky, 1991.

Krippendorff, Klaus. Content Analysis: An Introduction to Its Methodology. Thousand Oakes: Sage, 2004.

Loewen, James. Teaching What Really Happened. New York: Teachers College Press, 2010.

Lower, Wendy. Nazi Empire Building and the Holocaust in the Ukraine. Chapel Hill: University of North Carolina Press, 2005.

Marrus, Michael. The Holocaust in History. London: Weiderfeld \& Nicolson, 1987.

Marsden, William E. The School Textbook: Geography, History, and Social Studies. London: Woburn, 2001

Matthäus, Jurgen. "Agents of the Final Solution." In Holocaust Historiography in Context: Emergence, Challenges, Polemics and Achievements, edited by David Bankier and Dan Michman. Jerusalem: Yad Vashem, 2008.

Michaels, Deborah L. "Holocaust Education in the "Black Hole of Europe": Slovakia's Identity Politics and History Textbooks Pre- and Post-1989." Intercultural Education 24, no. 1-2 (2013): 19-40.

Mikk, Jaan. Textbook: Research and Writing. Frankfurt am Main: Peter Lang, 2000.

Mirkovic, Marijana, and Keith Crawford. "Teaching History in Serbian and English Secondary Schools: A Cross-Cultural Analysis of Textbooks". International Journal of Historical Learning, Teaching and Research 3, no. 2 (2003): 91-106.

Nicholls, Jason, and Stuart J. Foster. "Portrayal of the SovIiet Role in World War II: An Analysis of School History Textbooks from England and the USA." In International School Textbooks and Educational Media Conference. Edge Hill College of Higher Education, England, 2003.

Nicholls, Jason. "Beyond the National and the Transnational: Perspectives of WWII in U.S.A, Italian, Swedish, Japanese, and English School History Textbooks." In What Shall We Tell the Children? International Perspectives on School History Textbooks, edited by Stuart J. Foster and Keith A. Crawford. Greenwich, Connecticut: Information Age Publishing, 2006. 
Nicholls, Jason. "Methods in School Textbook Research." International Journal of Historical Learning, Teaching and Research 3, no. 2 (2003): 11-26.

Nicholls, Jason. "The Philosophical Underpinnings of School Textbook Research." Paradigm 3, no. 1 (2003): 24-35.

Nicholls, Jason. School History Textbooks across Cultures. International Debates and Perspectives. Oxford: Symposium, 2006.

Pearce, Andy. Holocaust Consciousness in Contemporary Britain. New York: Routledge, 2014.

Pettigrew, Alice, Stuart Foster, Jonathan Howson, Paul Salmons, Ruth-Anne Lenga, and Kay Andrews. Teaching about the Holocaust in English Secondary School: An Empirical Study of National Trends, Perspectives and Practice. London: Institute of Education, 2009.

Phillips, Robert. History Teaching, Nationhood and the State: A Study in Educational Politics. London: Cassell, 1998.

Pingel, Falk. The European Home: Representations of 20th Century Europe in History Textbooks. Strasbourg: Council of Europe, 2000.

Pingel, Falk. Unesco Guidebook on Textbook Research and Textbook Revision. Georg Eckert Institute and Unesco, 1999.

Qualifications and Curriculum Authority. History. Programme of Study for Key Stage 3 and Attainment Targets. London: Crown, 2007.

Qualifications and Curriculum Authority. Schemes of Work: History at Key Stage 3. 2000.

Russell, Lucy. Teaching the Holocaust in School History. London and New York: Continuum International Publishing Group, 2006.

Sleeter, Christine, and Carl Grant. "Race, Class, Gender and Disability in Current Textbooks". In The Politics of the Textbook, edited by Michael Apple and Linda Christian-Smith. New York and London: Routledge, 1991.

Snyder, Timothy. Bloodlands: Europe between Hitler and Stalin. New York: Basic Books, 2010 .

Stone, Dan. Histories of the Holocaust. Oxford: Oxford University Press, 2010.

Supple, Carrie. The Teaching of the Nazi Holocaust in North Tyneside, Newcastle and Northumberland Secondary Schools, PhD thesis, University of Newcastle-upon-Tyne, 1992.

Sylvester, David. "Change and Continuity in History Teaching 1900-1992." In Teaching History, edited by Hilary Bourdillon. London: Open University Press, 1994.

Verschaffel, Tom and Kaat Wils "History Education and the Claims of Society: An historical Approach.' Journal of Educational Media, Memory and Society, Vol. 4, no.1 (2012): 16. 
Wasburn, Leah. "Accounts of Slavery: An Analysis of the United States History Textboosk from 1900-1992." Theory and Research in Social Education 25, no. 4 (1997): 470-91.

Weinbrenner, P. "Methodologies of Textbook Analysis Used to Date." In History and Social Sciences - Methodologies of Textbook Analysis. Report of the Educational Research Workshop Held in Braunschweig (Germany) 11-14 September 1990, edited by Hilary Bourdillon. Amsterdam: Swets \& Zeitlinger, 1992.

Wenzeler, Barbara M. "The Presentations of the Holocaust in German and English School History Textbooks. A Comparative Study." International Journal of Historical Learning, Teaching and Research 3, no. 2 (2003): 107-18.

Westbury, Ian. "Teaching as a Reflective Practice: What Might Didaktik Teach Curriculum?". In Teaching as a Reflective Practice: The German Didaktik Tradition, edited by Ian Westbury, Stefan Hopmann and Kurt Riquarts, 15-39. London: Routledge, 2000.

Williams, Raymond. Culture and Society 1780-1950. Harmondsworth: Penguin Chatto \& Windus, 1961.

Witschonke, Christopher. "A 'Curtain of Ignorance': An Analysis of Holocaust Portrayal in Textbooks from 1943 through 1959". The Social Studies 104, no. 4 (2013): 146-54. 